\title{
A Reanalysis of the 1931-43 Atlantic Hurricane Database*
}

\author{
Christopher W. LANDSEA, ${ }^{+}$Andrew Hagen, ${ }^{\#}$ William Bredemeyer, ${ }^{\#}$ Cristina Carrasco,

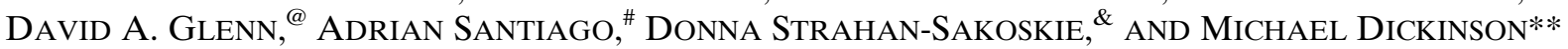 \\ ${ }^{+}$NOAA/NWS/NCEP/National Hurricane Center, Miami, Florida \\ ${ }^{\#}$ Cooperative Institute for Marine and Atmospheric Studies (CIMAS), University of Miami, Miami, Florida \\ ${ }^{\circledR}$ NOAA/NWS/WFO Morehead City, Morehead City, North Carolina \\ \& University of North Carolina at Charlotte, Charlotte, North Carolina \\ ** WeatherPredict Consulting, Inc., Wakefield, Rhode Island
}

(Manuscript received 19 August 2013, in final form 19 January 2014)

\begin{abstract}
A reanalysis of the Atlantic basin tropical storm and hurricane database ("best track") for the period from 1931 to 1943 has been completed as part of the Atlantic Hurricane Database Reanalysis Project. This reassessment of the main archive for tropical cyclones of the North Atlantic Ocean, Caribbean Sea, and Gulf of Mexico was necessary to correct systematic biases and random errors in the data as well as to search for previously unrecognized systems. Methodology for the reanalysis process for revising the track and intensity of tropical cyclone data is largely unchanged from that of the preceding couple of decades and has been detailed in a previous paper on the reanalysis. Accurate Environmental Forecasting's numerical weather prediction-based wind field model was utilized here to help determine which states were impacted by various hurricane force winds in several U.S. landfalling major hurricanes during this era. The 1931-43 dataset now includes 23 new tropical cyclones, excludes five systems previously considered tropical storms, makes generally large alterations in the intensity estimates of most tropical cyclones (at various times both toward stronger and weaker intensities), and typically adjusts existing tracks with minor corrections. Average errors in intensity and track values are estimated for both open ocean conditions as well as for landfalling systems. Finally, highlights are given for changes to the more significant hurricanes to impact the United States, Central America, and the Caribbean for this time period.
\end{abstract}

\section{Introduction}

This paper details efforts to reanalyze the National Hurricane Center (NHC)'s second-generation North Atlantic Hurricane Database (HURDAT2; Landsea and Franklin 2013), also called the "best track" since they are the "best" postseason determination of tropical cyclone (TC) tracks and intensities for the period from 1931 to 1943. Previous work as part of the Atlantic Hurricane Database Reanalysis Project that has been

\footnotetext{
* Supplemental information related to this paper is available at the Journals Online website: http://dx.doi.org/10.1175/JCLI-D-1300503.s1.

Corresponding author address: Christopher W. Landsea, NOAA/ NWS/NCEP/National Hurricane Center, 11695 SW 17th Street, Miami, Florida, 33165.

E-mail: chris.landsea@noaa.gov
}

officially included in the HURDAT2 dataset includes the periods of 1851-1910 (Landsea et al. 2004a), 1911-20 (Landsea et al. 2008), and 1921-30 (Landsea et al. 2012), as well as 1969's Hurricane Camille (Landsea et al. 2014) and 1992's Hurricane Andrew (Landsea et al. 2004b). Additionally, revisions to the hurricane database have been proposed for the period of 1944 through 1953 (Hagen et al. 2012). As the methodology and observational data are nearly identical to that reported for the 1911-30 reanalysis efforts, the reader is referred to Landsea et al. $(2008,2012)$ for discussion of datasets utilized and general methodology employed. (See the supplemental material including Fig. S1 and Table S1 for an example of the reanalysis-the 1938 Great New England Hurricane.) One important new tool-Accurate Environmental Forecasting (AEF)'s numerical weather prediction-based wind field model (hereafter, the AEF wind model) (Dickinson et al. 2004)—was employed for analyzing the wind field for some U.S. major hurricanes of this era to provide an 
additional method for determining which states were impacted by what category [on the Saffir-Simpson hurricane wind scale (SSHWS)] hurricane force winds.

\section{New datasets and methodology}

The limited observational capabilities of the 1930s and early 1940s were quite similar to that of the previous few decades: measurements from unfortunately placed ships at sea and from coastal weather stations (Landsea et al. 2004a, 2008, 2012). Methodology for reexamining the existing track, intensity, and classification of TCs, for uncovering previously unidentified TCs, and for potentially removing TCs from the database is detailed in Landsea et al. $(2008,2012)$ and is unchanged from what was utilized here for 1931-43.

One new study that was considered in the reanalysis efforts was the storm surge observations and modeling work by Jarvinen (2006). This paper addressed several very destructive U.S. landfalling hurricanes from the framework of observed storm surge observations and matched them based upon storm surge runs from the Sea, Lake, and Overland Surges from Hurricanes (SLOSH) model (Jelesnianski et al. 1992). His results provided revised tracks, central pressures, and maximum sustained winds for hurricanes that included the 1935 Labor Day Hurricane and the 1938 Great New England Hurricane.

The reanalysis efforts also incorporated output from the AEF wind model to provide objective guidance on what tropical storm and hurricane force winds affected which states for several destructive landfalling U.S. hurricanes. The AEF wind model (Dickinson et al. 2004) is based on the operational Geophysical Fluid Dynamics Laboratory (GFDL) hurricane forecast model (Kurihara et al. 1998) that uses a multiple-nested movable mesh system to depict the interior structure of tropical cyclones with grid spacing of $12 \mathrm{~km}$ on the innermost grid. The GFDL model has been extensively modified to permit simulations of the wind field produced by a hurricane with a prescribed track and intensity. The AEF wind model is a dynamical model that utilizes the physical balances in the dynamic equations to determine how a TC will respond to local variability in the surface conditions (primarily topography and surface roughness). The AEF wind model incorporates a high-resolution boundary layer (eight vertical levels below $1000 \mathrm{~m}$ ) combined with high-resolution information about topography and land use. The model does not use data assimilation per se, but the wind field is determined by the model through specification of the TC location, maximum wind, and radius of maximum wind (if available) at a 6-hourly interval to be consistent with that in the original and revised HURDAT2. [Note that as the HURDAT2 database is provided in 5-kt increments, knots $\left(\mathrm{kt} ; 1 \mathrm{kt} \approx 0.5144 \mathrm{~m} \mathrm{~s}^{-1}\right)$ will be the unit of preference here for wind speed.] The AEF wind model is well suited to study recent or historical hurricane events.

The last hurricane season included in this report (1943) heralded the first use of aircraft reconnaissance for monitoring tropical cyclones in the Atlantic basin. The first two flights into a hurricane, quite serendipitously, were those by U.S. Colonel Joseph P. Duckworth, an officer of the Army Air Corps, on 27 July 1943. As documented in Sumner (1943), "this is the first time...that a plane has been intentionally flown through the center of a hurricane." (A detailed report by Duckworth about these flights, previously unpublished, is included as Fig. S2 in the supplemental material.) Later in the same season came the first operational report available to the U.S. Weather Bureau office in Miami, Florida, where the primary U.S. hurricane analysis and forecasting was newly being conducted (in conjunction with the U.S. Navy and the U.S. Army Air Corps). As described in Hagen et al. (2012), beginning with this newly centralized office for hurricane prediction, an archive of microfilm imagery of the handdrawn surface weather maps has been maintained at the National Hurricane Center library. Figure 1 shows this first real-time report (provided by two-way radio) received by the Miami Weather Bureau on 16 August 1943 of a tropical storm east of the United States. Additional ad hoc hurricane flights were taken later in the season. Such monitoring evolved over the next few years into a formalized reconnaissance program by the U.S. Navy and the U.S. Army Air Corps (now the U.S. Air Force), which allowed for the advance notification of potentially landfalling hurricanes to affect the United States and countries throughout the Caribbean and Central America.

\section{Track, intensity, and frequency error estimates}

Given that the observational datasets for TCs during 1931-43 were nearly the same as for previous decades and that the methodology for reanalysis had not substantially changed, estimates for errors and biases are unchanged from the previous decades (Table 1). The estimated average position errors do depend on whether the TC was out over the open ocean or making landfall, the former being significantly uncertain $(\sim 100 \mathrm{nmi} ; 1 \mathrm{nmi}=1852 \mathrm{~m})$ and the latter more accurate $(\sim 60 \mathrm{nmi})$. It is estimated that the intensity measurements for 1931-43 were in error an average of $20 \mathrm{kt}$ over the open ocean, with a substantial bias toward underestimating the true intensity (Tables 2 and 3). For TCs landfalls during the 1930s and early 1940s, errors in the intensity estimates are smaller $(\sim 15 \mathrm{kt})$ and 


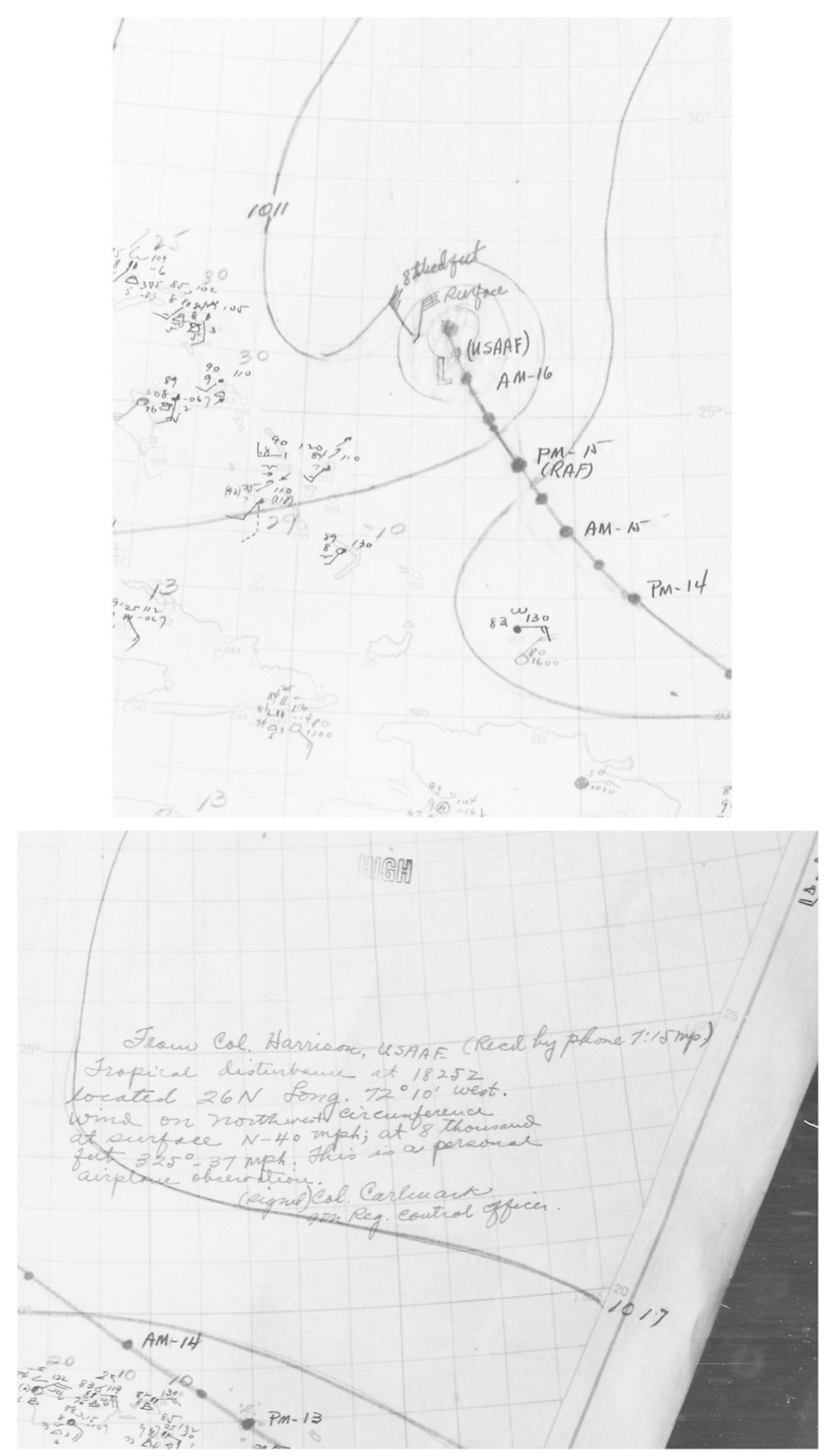

FIG. 1. First operational use of aircraft reconnaissance for tropical cyclone analysis and prediction on 16 Aug 1943. The handwritten text states: "From Col. Harrison, USAAF (Recd by phone $7: 15 \mathrm{pm}$ ) Tropical disturbance at $1825 \mathrm{Z}$ located $26 \mathrm{~N}$ Long. $72^{\circ} 10^{\prime}$ west. Wind on northwest circumference at surface $\mathrm{N}-40 \mathrm{mph}$; at 8 thousand feet $325^{\circ}-37 \mathrm{mph}$. This is a personal airplane observation. (signed) Col. Carlwark 9th Reg. Control Officer." 
TABLE 1. Estimated average position uncertainty (nmi) in the revised best track for the years 1851-1953 and in the existing best track for the late 1990s-late 2000s. Here and in the subsequent tables N/A indicates not applicable. [The period 1851-1910 is discussed in Landsea et al. (2004a), 1911-20 is discussed in Landsea et al. (2008), 1921-30 is discussed in Landsea et al. (2012), 1931-43 is discussed in this paper, 1944-53 is discussed in Hagen et al. (2012), and late 1990s-late 2000s is discussed in Landsea and Franklin (2013). By the 1920s, nearly all coastal areas in the Atlantic basin were relatively settled and monitored (Landsea et al. 2008).]

\begin{tabular}{lccc}
\hline \hline \multicolumn{1}{c}{ Dates } & $\begin{array}{c}\text { Landfall along } \\
\text { settled coast }\end{array}$ & $\begin{array}{c}\text { Open ocean with aircraft } \\
\text { reconnaissance }\end{array}$ & $\begin{array}{c}\text { Open ocean without aircraft } \\
\text { reconnaissance (or landfall along } \\
\text { unpopulated coast) }\end{array}$ \\
\hline $1851-85$ & 60 & N/A & 120 \\
$1886-1943$ & 60 & N/A & 100 \\
1944-53 & 20 & 35 & 80 \\
Late 1990s-late 2000s & 12 & 15 & 25 \\
\hline
\end{tabular}

likely have a negligible bias as nearly all coastlines around the western North Atlantic, Gulf of Mexico, and Caribbean Sea were substantially settled and monitored by then. These estimated errors are the same as the preceding couple of decades. Landsea et al. $(2008,2012)$ have additional information on the position and intensity error estimates for the reanalysis database relevant for this decade.

Methodology developed by Vecchi and Knutson (2008) allows for more reliable estimates of the number of "missing" TCs before the advent of satellite imagery. Their results suggest that about one tropical cyclone was missed every other year during the 1930 s, but this increased to about 2-3 $\mathrm{yr}^{-1}$ during 1940-43 resulting from much lower ship observation availability during World War II. Landsea et al. (2010) also indicated that there had been an extreme increase in the number of short-lived (less than or equal to a 2-day duration of tropical storm or greater intensity) TCs in the last couple of decades, which is likely due to better technology and monitoring of these short-lived and typically very weak systems (Villarini et al. 2011). Additionally, Vecchi and Knutson (2011) applied the same methodology toward estimates in the number of missed hurricanes, either those missed completely from the HURDAT2 database or those wrongly considered to be only of tropical storm intensity. The results of these incomplete sampling studies will be put into the context of the results of the reanalysis, which has led to a substantial change in the frequency of TCs and hurricanes.

\section{Results}

\section{a. Overall activity}

A summary of the yearly changes to HURDAT2 is provided in Fig. 2 and Table 4. Figure 2 shows the revised and comparison track maps for the individual seasons from 1931 to 1943. It is apparent that most of the track changes introduced for these years are fairly minor (less than a 120nmi alteration in position anytime during the TC's lifetime) as readily seen in the comparison maps, although there are some more dramatic alterations on occasion (e.g., storm 9 in 1932, storm 8 in 1934, and storm 10 in 1942). Despite making relatively minor changes overall, nearly every existing TC was adjusted for at least some portion of its track.

In addition to track alterations of existing systems, 23 new TCs were discovered and added into HURDAT2 (see Fig. S3 in the supplemental material) and five existing systems in HURDAT2 were reanalyzed to not be a tropical storm and thus removed from the database. Of the 23 new TCs that had sufficient observational evidence to document their existence and were thus added into HURDAT2, there were 4 in 1931 and 1932; 3 in 1934; 2 in 1933, 1935, 1937, and 1938; 1 in 1936, 1939, 1940, and 1942; and no new systems in 1941 and 1943. Of these 23, 6 of the new TCs were landfalling systems: storm 5 of 1931 in the Dominican Republic; storm 12 of 1931 in Mexico and Belize; storm 6 of 1934 in the United States; storm 1 of 1935 in the Dominican Republic; storm 7 of 1940 (as a hurricane) in the Azores; and storm 1 of 1942 in Mexico. Thus, while the majority of newly discovered tropical cyclones were over the open ocean, on occasion the reanalysis is able to add new landfalling tropical cyclones even in the first half of the twentieth century. ${ }^{1}$ Of the five systems during 1931-43 that were removed from the database, two (original storm 7 and storm 17 , both in 1933) were determined to have only reached tropical depression intensity, two (original

\footnotetext{
${ }^{1}$ Adding about two new tropical storms per year during this period appears at first glance to not be compatible with the estimate of missing storms provided by Vecchi and Knutson (2008), who suggested only about one storm every two years was not included into HURDAT for the decade of the 1930s. The inclusion of these new storms was because of a combination of observations available from Monthly Weather Review, Historical Weather Maps, the Comprehensive Ocean Atmosphere Dataset, and other sources. Thus, many of the previous noninclusions of these systems were a result of the failure of contemporary meteorologists to recognize them as tropical cyclones. The estimate of Vecchi and Knutson of missed storms still remains valid, as their assumption was that all available observations had already been thoroughly searched. Their assumption is now closer to being valid after the inclusion of all of these observational datasets.
} 
TABLE 2. Estimated average intensity uncertainty $(\mathrm{kt})$ in the revised best track for the years 1851-1953 and in the existing best tracks for the late 1990s and late 2000s. [The period 1851-1910 is discussed in Landsea et al. (2004a), 1911-20 is discussed in Landsea et al. (2008), 1921-30 is discussed in Landsea et al. (2012), 1931-43 is discussed in this paper, 1944-53 is discussed in Hagen et al. (2012), and the late 1990s-late 2000s is discussed in Landsea and Franklin (2013). By the 1920s, nearly all coastal areas in the Atlantic basin were relatively settled and monitored (Landsea et al. 2008).]

\begin{tabular}{lcccc}
\hline \hline Dates & $\begin{array}{c}\text { Landfall along } \\
\text { settled coast }\end{array}$ & $\begin{array}{c}\text { Open ocean with aircraft } \\
\text { central pressure }\end{array}$ & $\begin{array}{c}\text { Open ocean with aircraft, } \\
\text { no central pressure }\end{array}$ & $\begin{array}{c}\text { Open ocean without aircraft } \\
\text { reconnaissance (or landfall along } \\
\text { unpopulated coast) }\end{array}$ \\
\hline $1851-85$ & 15 & N/A & N/A & 25 \\
$1886-1943$ & 15 & N/A & N/A & 20 \\
$1944-53$ & 11 & 13 & 17 & 20 \\
Late 1990s & 10 & 12 & N/A & 15 \\
Late 2000s & 9 & 10 & N/A & 12 \\
\hline
\end{tabular}

storm 1 of 1934 and storm 7 of 1938) were reanalyzed to have been extratropical in structure at the times that tropical storm force winds occurred, and, finally, one was removed because it was the continuation of an earlier, preexisting tropical cyclone (original storm 4 of 1933).

Table 4 lists the original and revised tallies of tropical storms and hurricanes, hurricanes, major hurricanes (categories 3, 4, and 5 on SSHWS), and accumulated cyclone energy (ACE; an index for overall TC activity that takes into account the total frequency, intensity, and duration of TCs; Bell et al. 2000). ACE is calculated by summing the squares of the estimated 6-hourly maximum wind speed in knots to be found in HURDAT2 for all periods while the system is either a tropical storm or hurricane.

The average number of recorded tropical storms and hurricanes increased from $10.0 \mathrm{yr}^{-1}$ in the original HURDAT2 to $11.4 \mathrm{yr}^{-1}$ after the reanalysis (Table 4), a $14 \%$ increase. This net increase accounts for the new systems that were added into the database as well as the removal of systems that were discarded from HURDAT2. The revised value is close to the long-term average of $12.1 \mathrm{yr}^{-1}$ recorded in the most recent (19812010) base period climatology. However, as described earlier, a direct comparison of the total frequency of TCs during the 1930s through early 1940s to the modern climatology is complicated by the occurrence of missed TCs in the earlier years due to the lack of satellite imagery and vastly improved monitoring capability available now. In the original HURDAT2, of the $130 \mathrm{TCs}$, only 11 were short-lived. With the reanalysis, of the 148 TCs for the 1931-43 period, 23 are now indicated to be short-lived TCs. Six of the newly described short-lived TCs were because of a decrease in the original duration recorded, seven were brand new TCs not previously recorded, and one previous short-lived TC was removed from HURDAT2. To better homogeneously compare the 1930s through early 1940s to the more recent era, one must estimate the number of missed TCs of medium to long durations in the 1931-43 period and remove the likely spurious influence of the short-lived TC trends. Using the results of Landsea et al. (2010), an average of about one medium to long-lived TC every two years was missed during 1931-39, and about $1.5 \mathrm{yr}^{-1}$ were missed during 1940-43. Thus, the best adjusted total of medium to long-lived TCs from 1931 to 1943 is about $10.4 \mathrm{yr}^{-1}$ (9.6 $\mathrm{yr}^{-1}$ recorded plus $0.8 \mathrm{yr}^{-1}$ missed), which suggests that this period was more active than today's 1981-2010 climatology of $8.4 \mathrm{yr}^{-1}$.

Measured hurricane frequency (Table 4) had a small increase from 4.8 to $5.3 \mathrm{yr}^{-1}$, which would appear to be below the $6.4 \mathrm{yr}^{-1}$ in the modern era climatology. However,

TABLE 3. Estimated average intensity error bias (kt) in the revised best track for the years 1851-1953 and in the existing best tracks for the late 1990s-late 2000s. Columns four through seven provide stratification of estimated bias by actual cyclone intensity when aircraft reconnaissance was monitoring the system but did not report a central pressure. [The period 1851-1910 is discussed in Landsea et al. (2004a), 1911-20 is discussed in Landsea et al. (2008), 1921-30 is discussed in Landsea et al. (2012), 1931-43 is discussed in this paper, 1944-53 is discussed in Hagen et al. (2012), and the late 1990s-late 2000s is discussed in Landsea and Franklin (2013). By the 1920s, nearly all coastal areas in the Atlantic basin were relatively settled and monitored (Landsea et al. 2008).]

\begin{tabular}{|c|c|c|c|c|c|c|c|}
\hline \multirow[b]{2}{*}{ Dates } & \multirow{2}{*}{$\begin{array}{l}\text { Landfall along } \\
\text { settled coast }\end{array}$} & \multirow{2}{*}{$\begin{array}{l}\text { Open ocean with } \\
\text { aircraft central } \\
\text { pressure }\end{array}$} & \multicolumn{4}{|c|}{$\begin{array}{c}\text { Open ocean with aircraft, } \\
\text { no central pressure }\end{array}$} & \multirow{2}{*}{$\begin{array}{l}\text { Open ocean without aircraft } \\
\text { reconnaissance (or landfall } \\
\text { along unpopulated coast) }\end{array}$} \\
\hline & & & $30-60 \mathrm{kt}$ & $65-95 \mathrm{kt}$ & $100-115 \mathrm{kt}$ & $120+\mathrm{kt}$ & \\
\hline $1851-85$ & 0 & N/A & N/A & N/A & N/A & N/A & -15 \\
\hline 1886-1943 & 0 & N/A & N/A & N/A & N/A & N/A & -10 \\
\hline $1944-53$ & 0 & 0 & +3 & +5 & 0 & -10 & -10 \\
\hline $\begin{array}{l}\text { Late } 1990 \mathrm{~s}-\text { late } \\
\quad 2000 \mathrm{~s}\end{array}$ & 0 & 0 & N/A & N/A & N/A & N/A & 0 \\
\hline
\end{tabular}



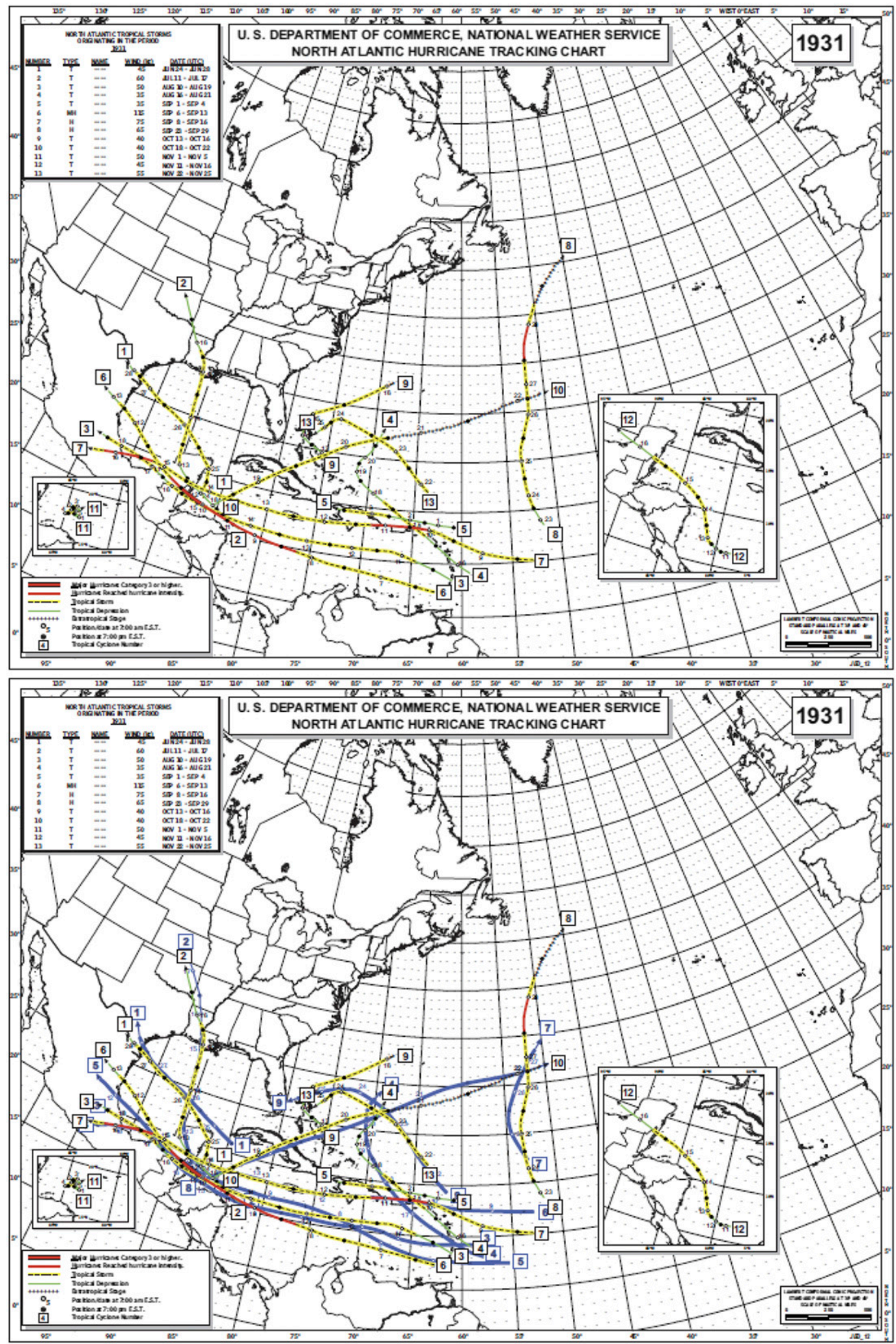

FIG. 2. The (top) revised and (bottom) comparison (with original storm numbers and tracks in blue underlying revised tracks) Atlantic basin TC track maps for 1931, 1932, 1933, 1934, 1935, 1936, 1937, 1938, 1939, 1940, 1941, 1942, and 1943. 

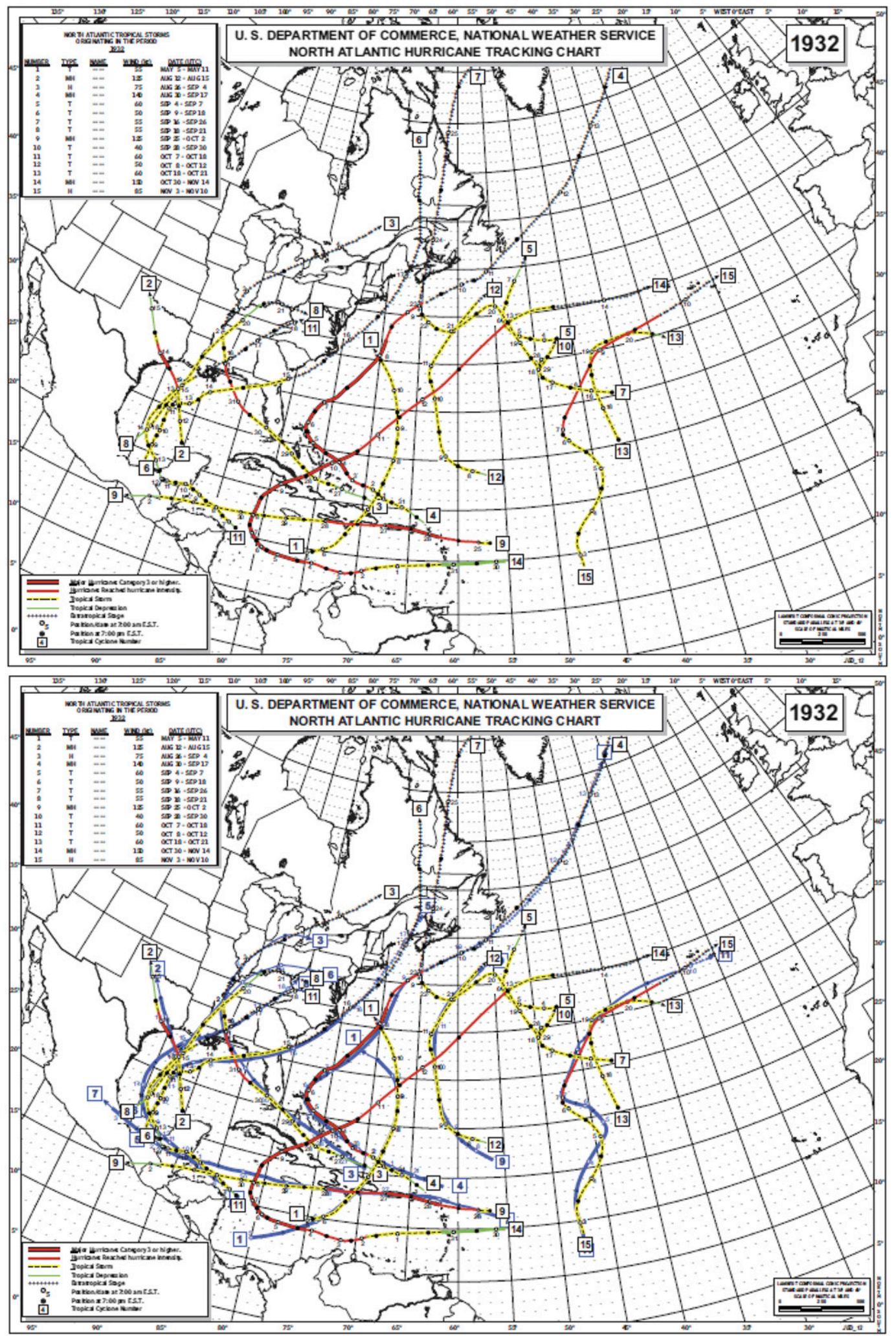

FIG. 2. (Continued) 

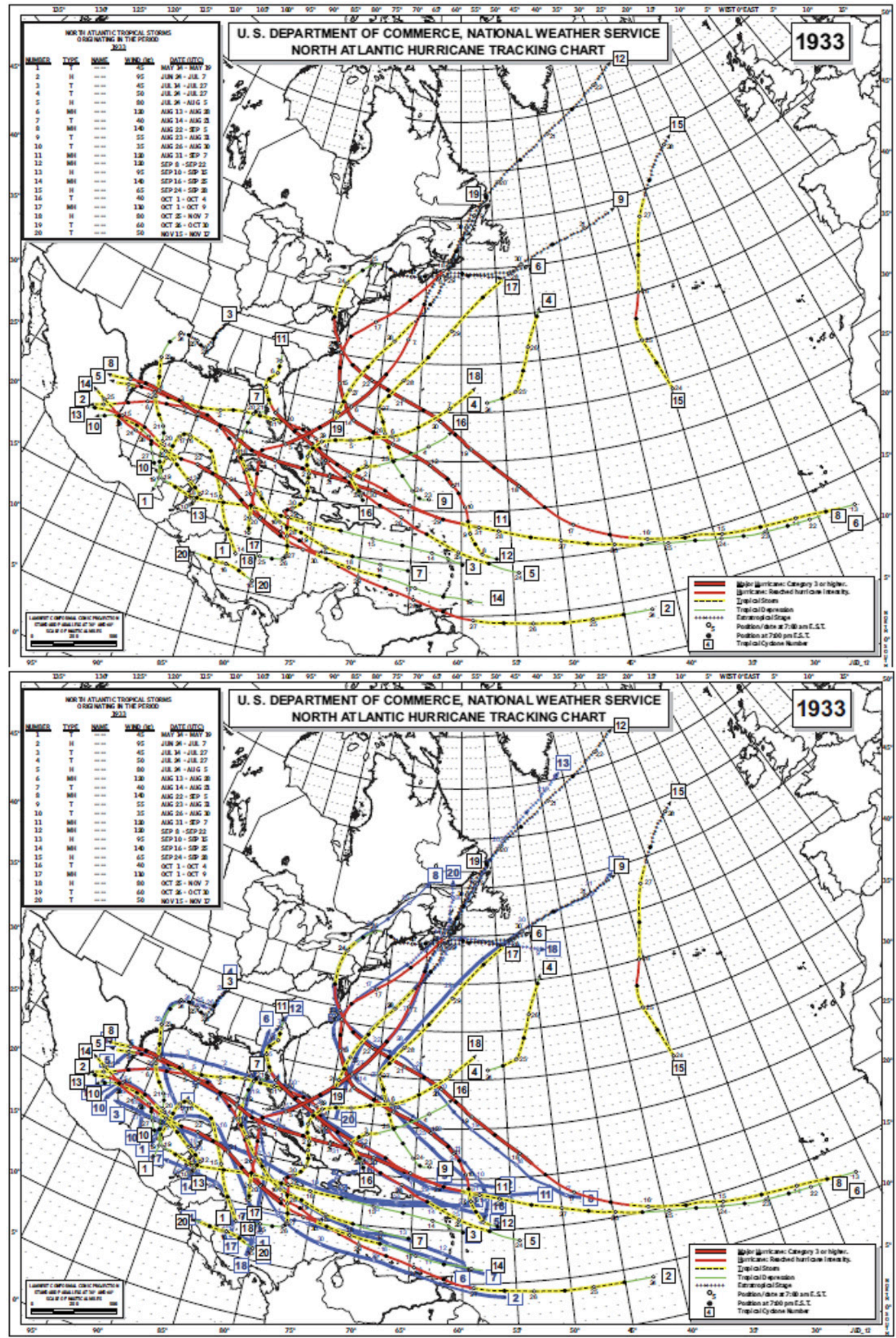

FIG. 2. (Continued) 

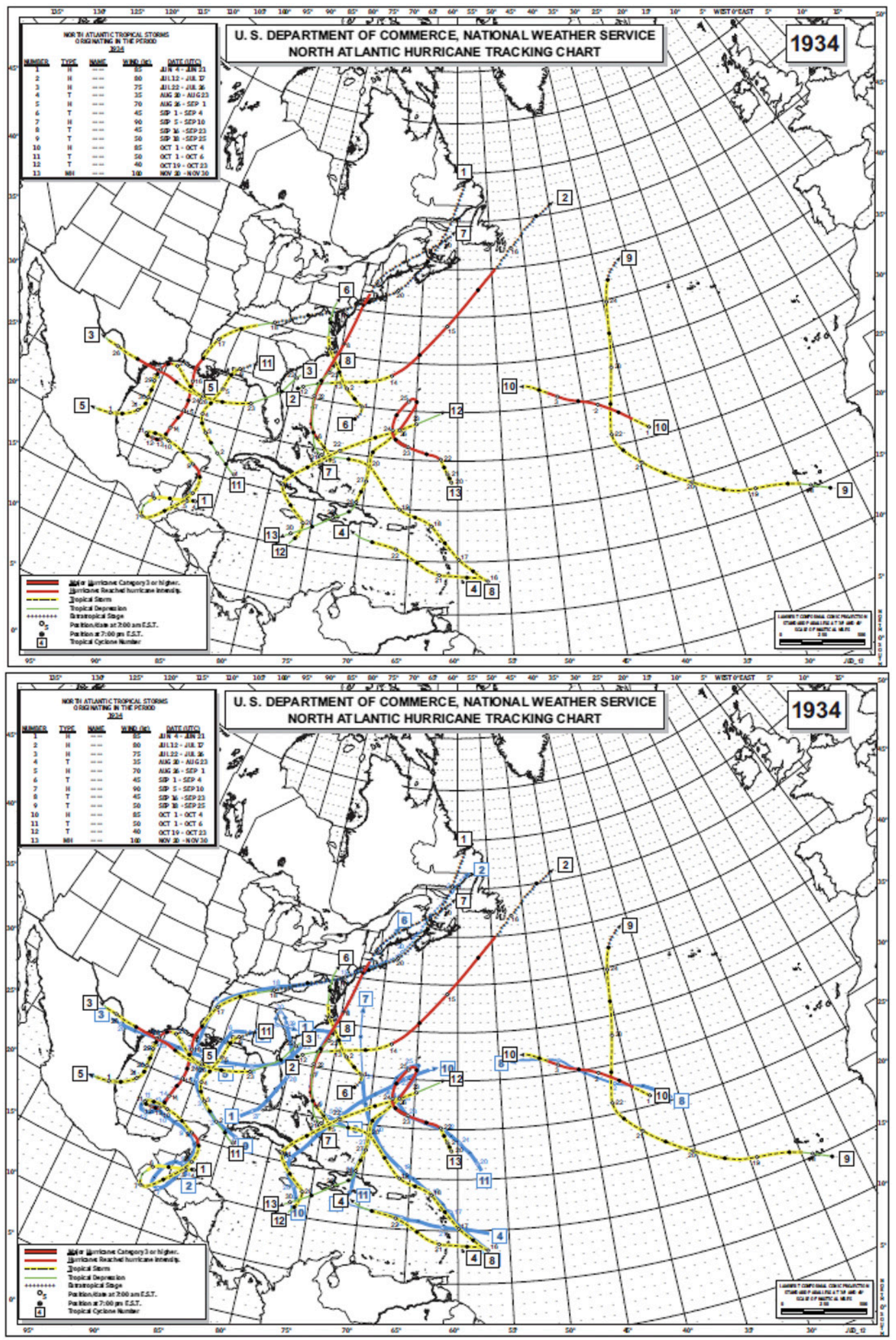

FIG. 2. (Continued) 

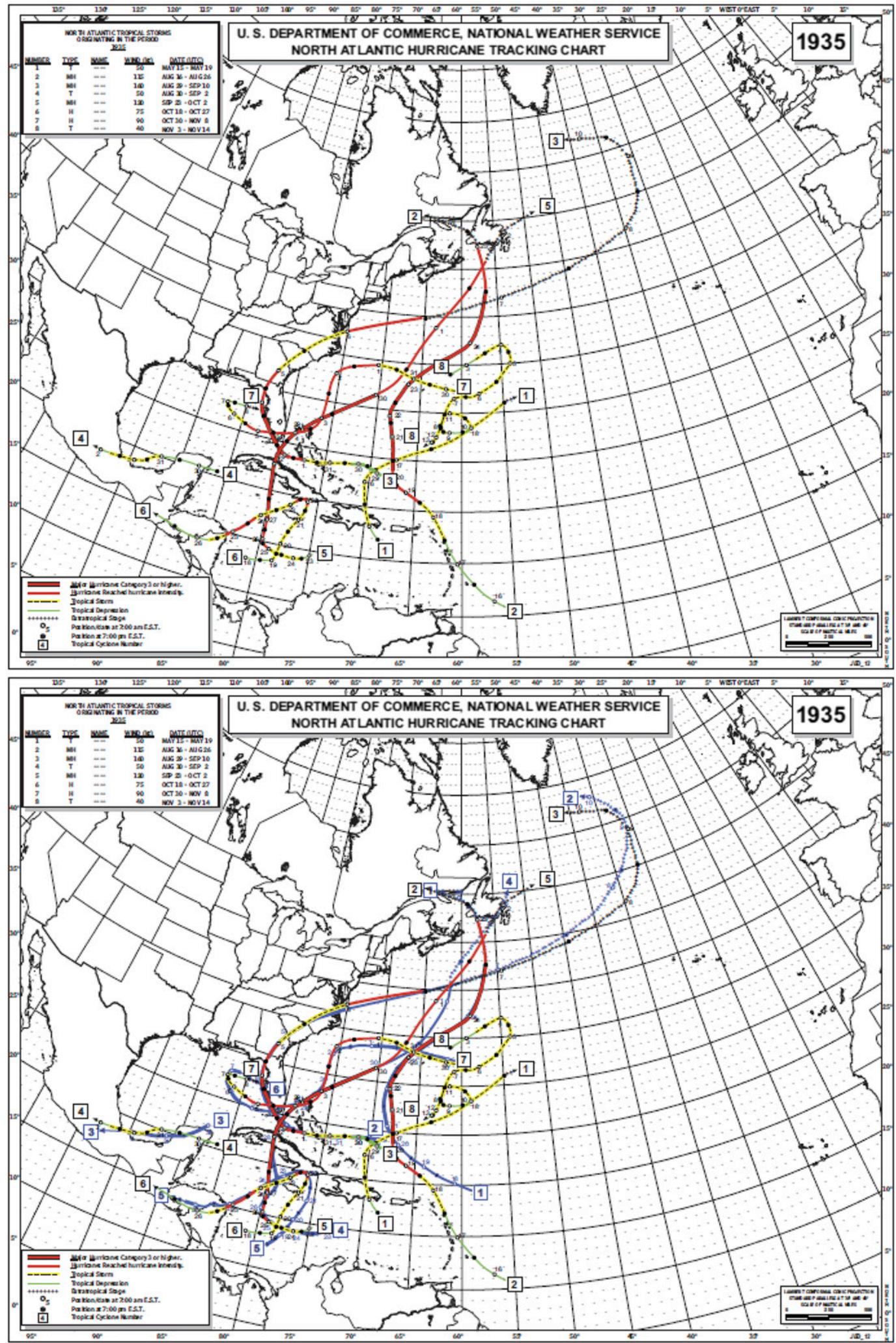

FIG. 2. (Continued) 

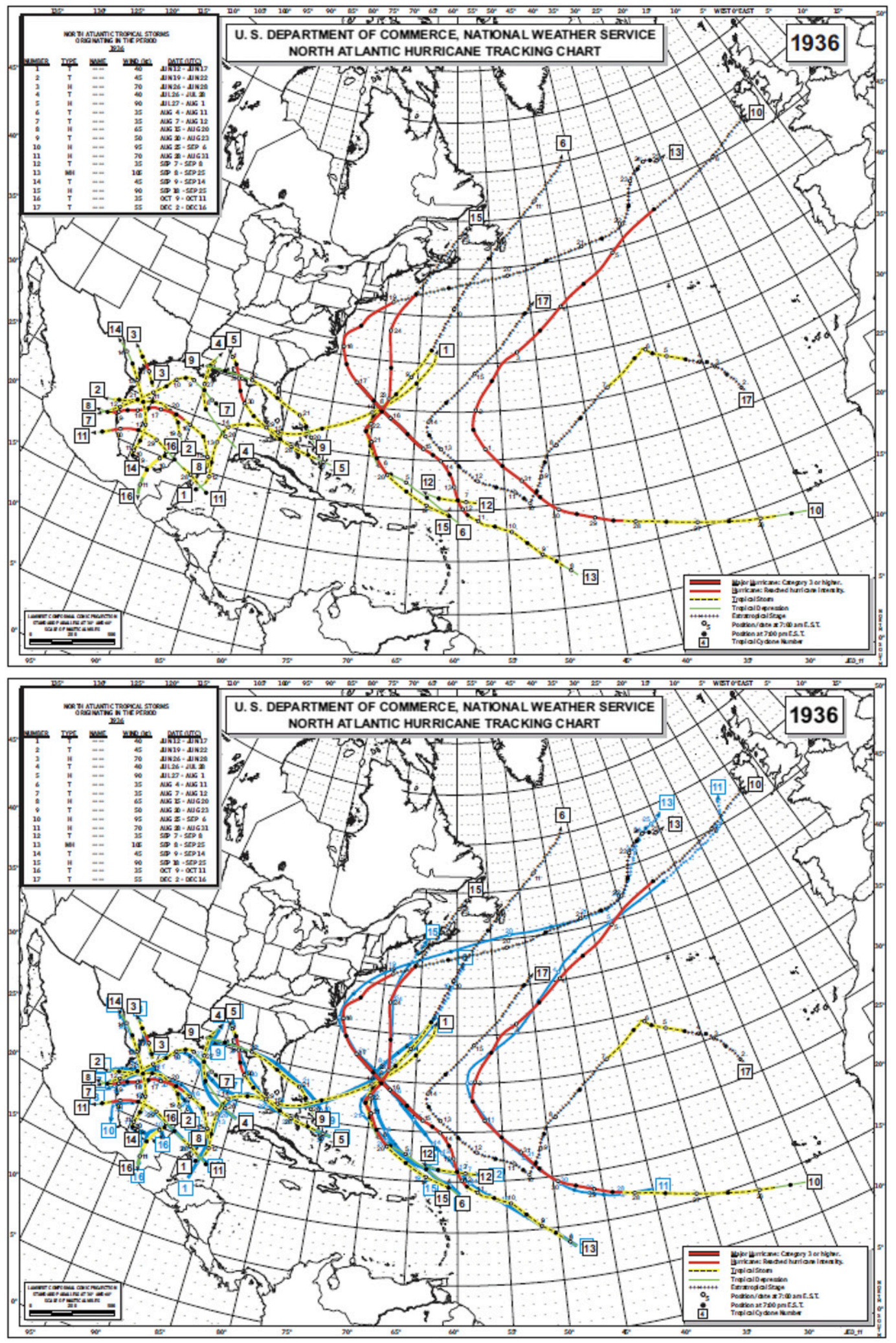

FIG. 2. (Continued) 

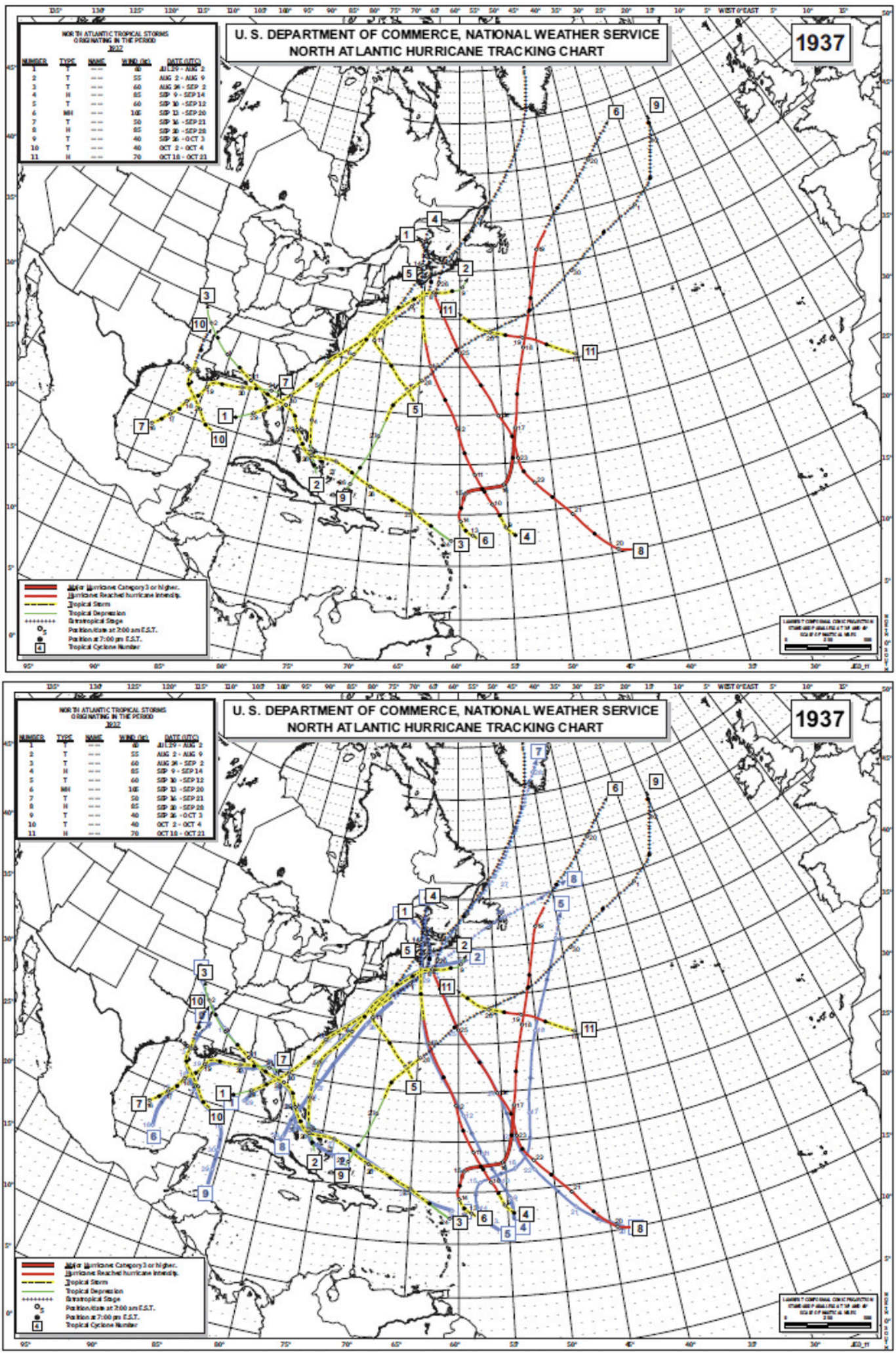

FIG. 2. (Continued) 

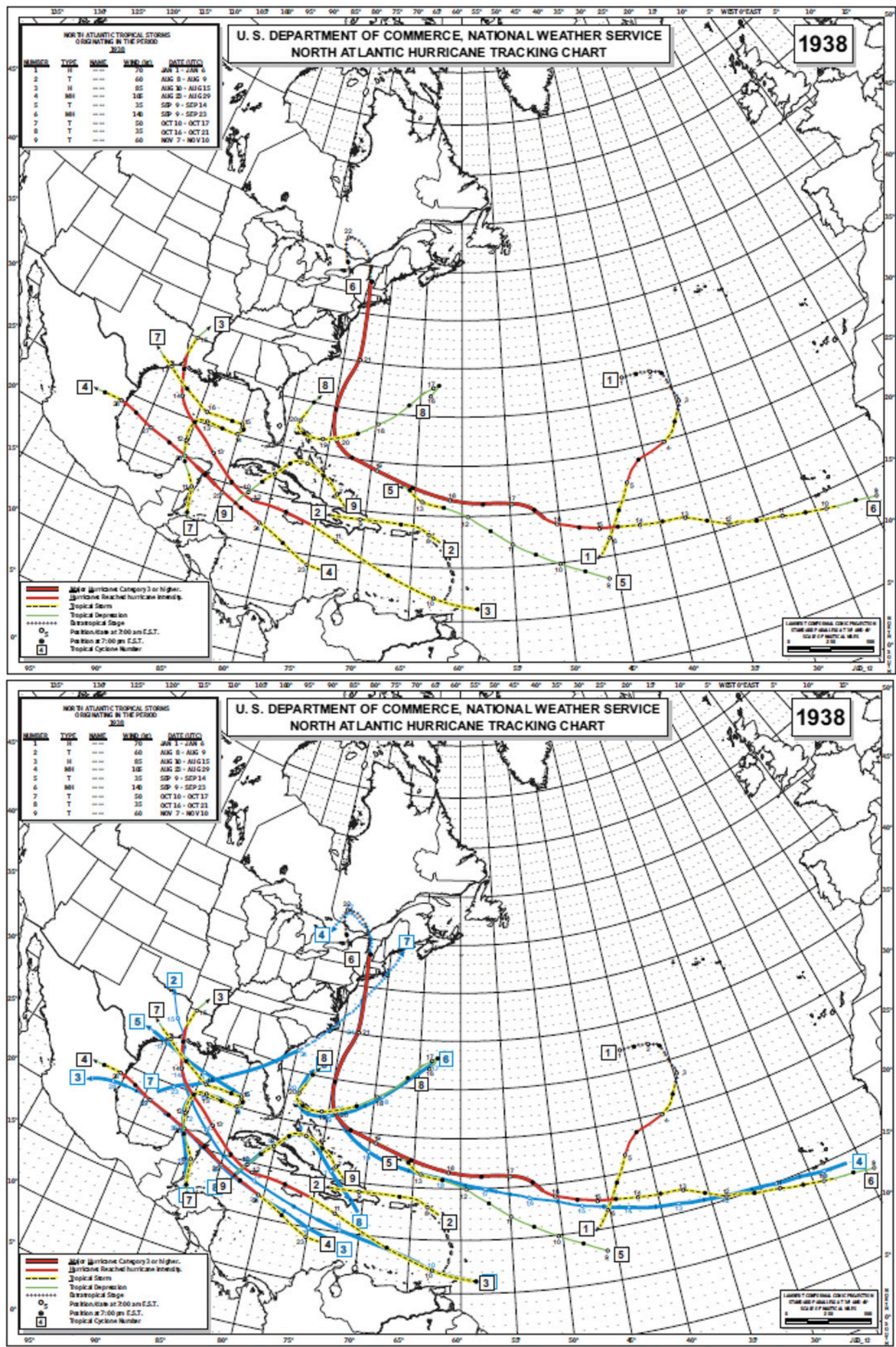

FIG. 2. (Continued) 

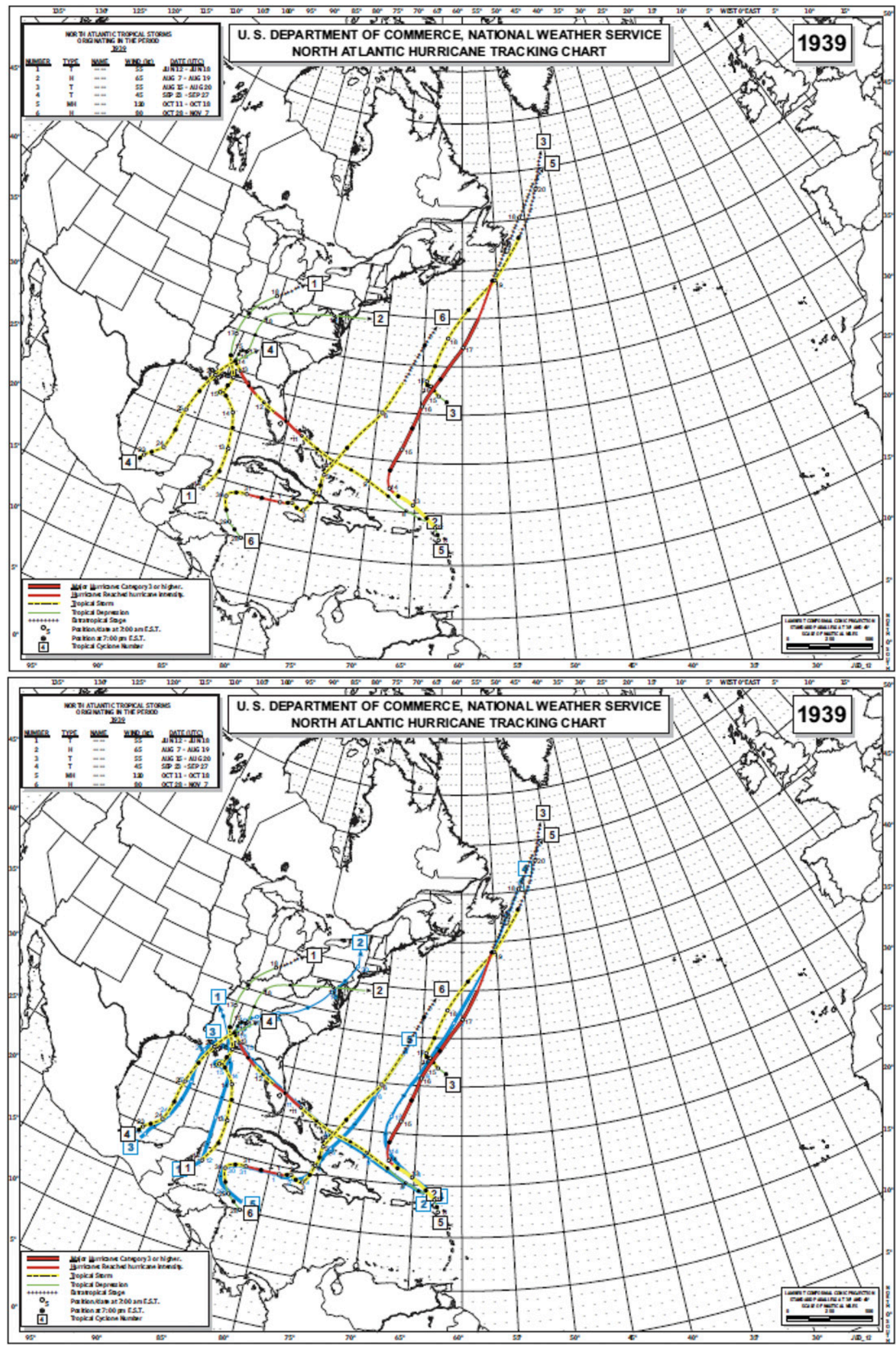

FIG. 2. (Continued) 

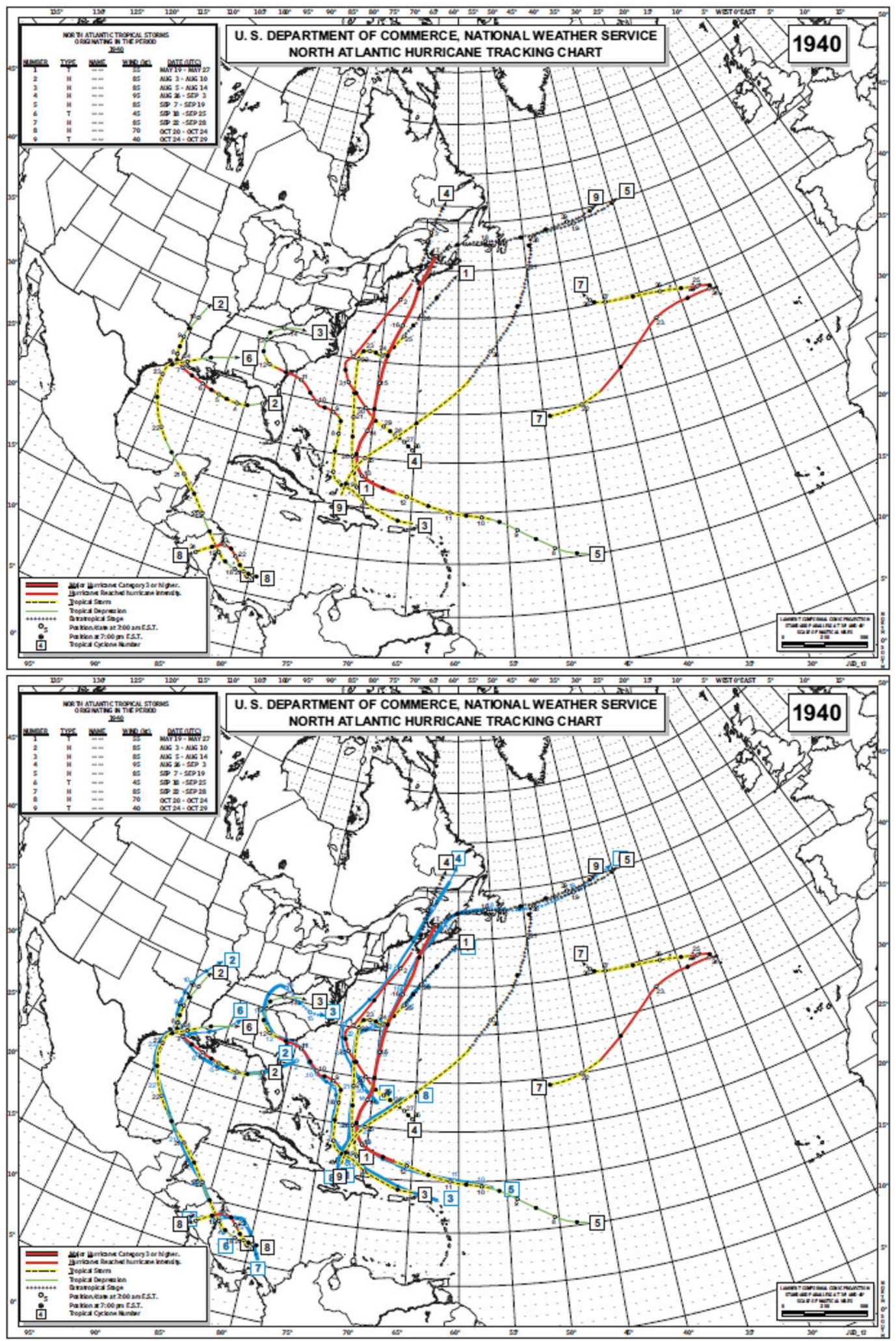

FIG. 2. (Continued) 

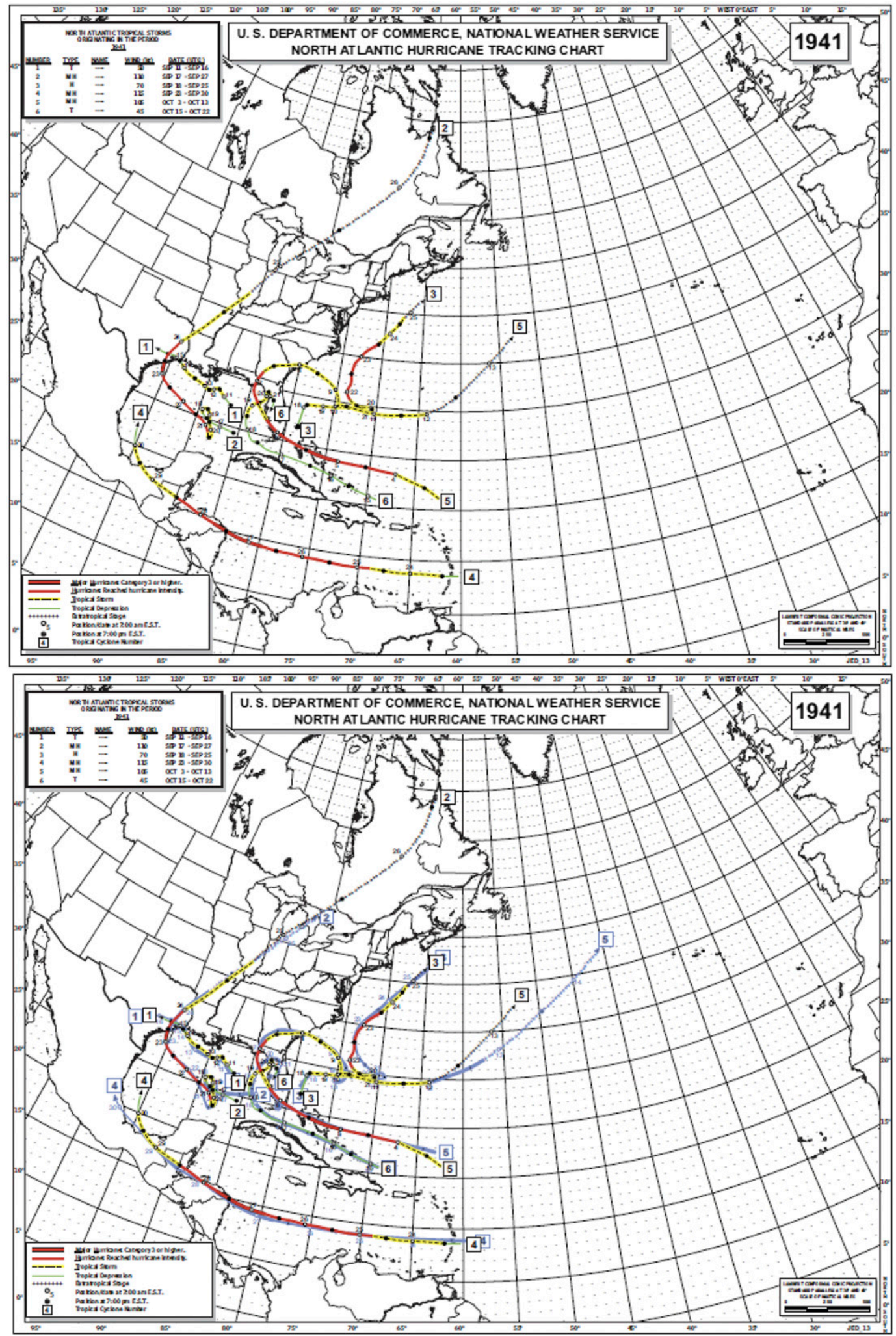

FIG. 2. (Continued) 

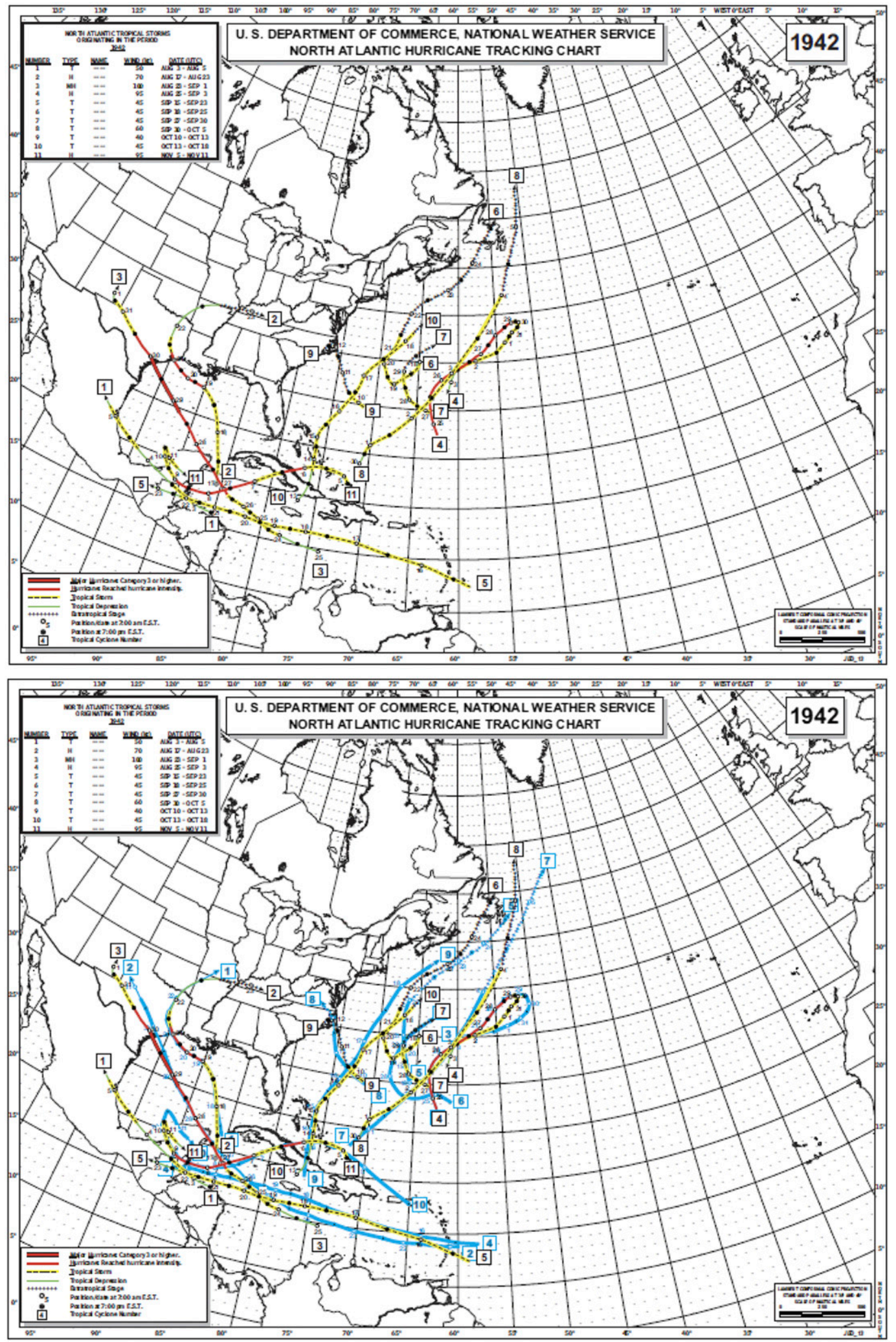

FIG. 2. (Continued) 

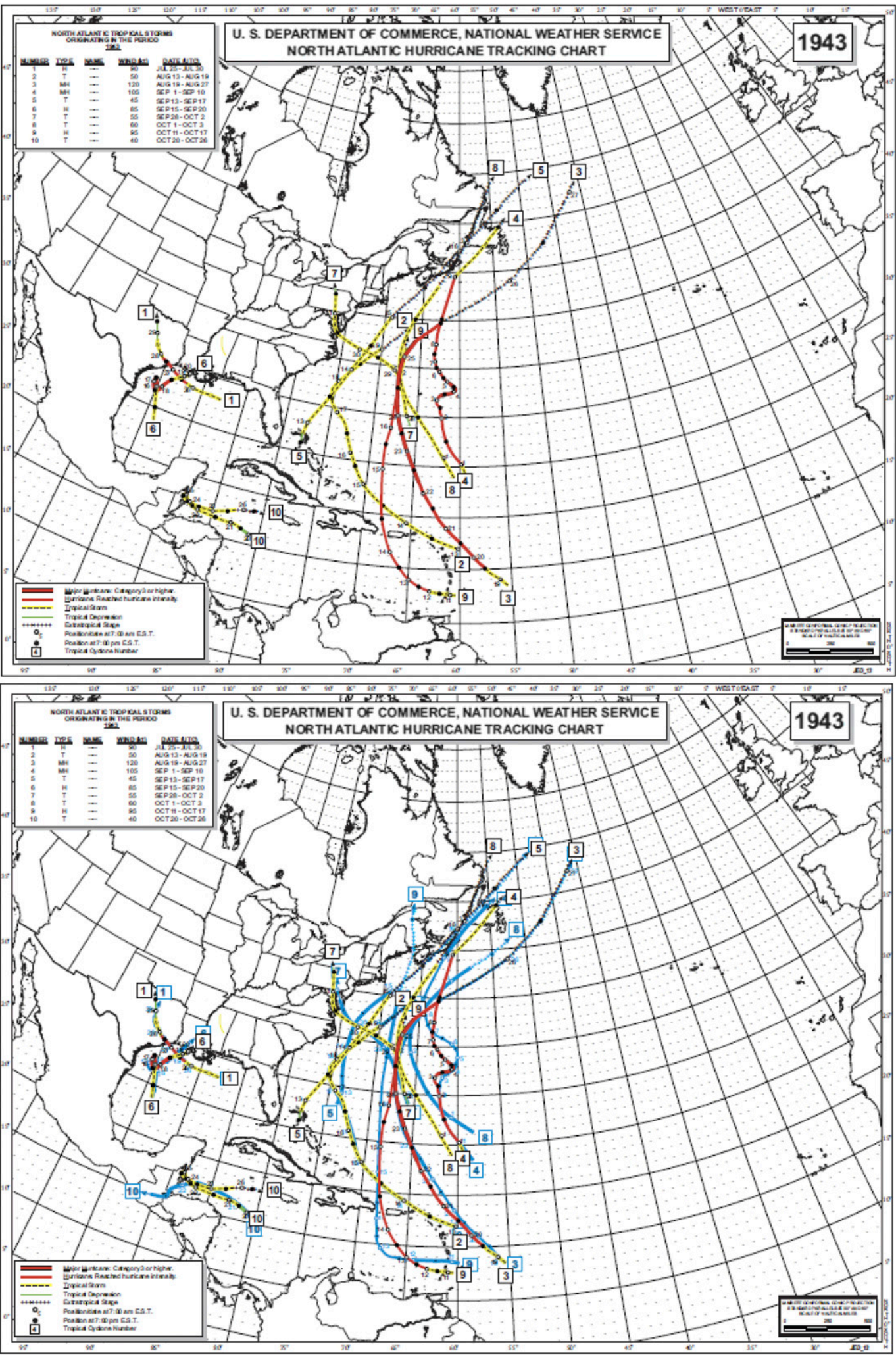

FIG. 2. (Continued) 
TABLE 4. Original (revised) tropical storm and hurricane, hurricane, major hurricane, and ACE counts. ACE is expressed in units of $10^{4} \mathrm{kt}^{2}$

\begin{tabular}{|c|c|c|c|c|}
\hline Year & $\begin{array}{c}\text { Tropical storms and } \\
\text { hurricanes }\end{array}$ & Hurricanes & Major hurricanes & $\mathrm{ACE}$ \\
\hline 1931 & $9(13)$ & $2(3)$ & $1(1)$ & $39(48)$ \\
\hline 1932 & $11(15)$ & $6(6)$ & $4(4)$ & $136(170)$ \\
\hline 1933 & $21(20)$ & $10(11)$ & $5(6)$ & $213(259)$ \\
\hline 1934 & $11(13)$ & $6(7)$ & $0(1)$ & $60(48)$ \\
\hline 1935 & $6(8)$ & $5(5)$ & $3(3)$ & 95 (106) \\
\hline 1936 & $16(17)$ & $7(7)$ & $1(1)$ & $108(100)$ \\
\hline 1937 & $9(11)$ & $3(4)$ & $0(1)$ & $61(66)$ \\
\hline 1938 & $8(9)$ & $3(4)$ & $1(2)$ & $73(78)$ \\
\hline 1939 & $5(6)$ & $3(3)$ & $1(1)$ & $34(34)$ \\
\hline 1940 & $8(9)$ & $4(6)$ & $0(0)$ & $52(68)$ \\
\hline 1941 & $6(6)$ & $4(4)$ & $2(3)$ & $61(52)$ \\
\hline 1942 & $10(11)$ & $4(4)$ & $1(1)$ & $66(63)$ \\
\hline 1943 & $10(10)$ & $5(5)$ & $2(2)$ & $94(94)$ \\
\hline Avg 1931-43 & $10.0(11.4)$ & $4.8(5.3)$ & $1.6(2.0)$ & $84.0(91.2)$ \\
\hline Avg 1981-2010 & 12.1 & 6.4 & 2.7 & 104.4 \\
\hline
\end{tabular}

Vecchi and Knutson (2011) estimated that HURDAT2 missed about one hurricane per year from 1931 to 1939 and about two hurricanes per year from 1940 to 1943. Including these undersampling estimates into the newly observed values suggests a total of about $6.5 \mathrm{yr}^{-1}$ hurricanes occurred during 1931-43, quite similar to the modern climatology.

Similarly, the major hurricane and ACE averages (Table 4) show modest increases in recorded values. Major hurricanes went from 1.6 up to $2.0 \mathrm{yr}^{-1}\left(2.7 \mathrm{yr}^{-1}\right.$ in the modern climatology), and ACE increased from 84.0 to $91.2 \mathrm{yr}^{-1}$ (104.4 $\mathrm{yr}^{-1}$ in the modern climatology). With regards to ACE, the records for four years had a substantial increase in activity (ACE higher by at least 10.0 in 1932, 1933, 1935, and 1940); one year had a large decrease in activity (ACE lower by at least 10.0 in 1934); and the remaining eight years had minor changes in overall intensity, duration, and frequency. In general, large revisions to intensity (at least a 20-kt alteration at some point in the TC's lifetime) were recordedboth upward and downward - for the majority of individual TCs, typically with more significant changes than those introduced for track. Currently, no method exists for quantifying the amount of missed major hurricanes and ACE for the era of the 1930s through early 1940s. ${ }^{2}$ Consequently, any direct comparison of these quantities to the modern era would not be appropriate, and the provided modern era numbers should be used cautiously in general comparisons of major hurricanes and ACE to the study period.

\footnotetext{
${ }^{2}$ Hagen and Landsea (2012) showed that the 10 most recent category 5 hurricanes, which occurred from 1992 to 2007 , would have been classified as substantially weaker hurricanes if they had occurred during the 1944-53 period. Without any aircraft reconnaissance, the recorded peak intensity of these hurricanes would have almost certainly been weaker still if they had occurred in the 1931-43 period.
}

\section{b. Continental U.S. hurricanes}

Table 5 summarizes the continental U.S. hurricanes for the period from 1931 to 1943 and the states impacted by these systems. U.S. hurricanes are defined as those hurricanes that are analyzed to cause maximum (1 min) surface $(10 \mathrm{~m})$ winds of at least $64 \mathrm{kt}$ for an open exposure on the coast or inland in the continental United States. Hurricanes that make a direct landfall with the circulation center (eye) of the system crossing the coast as well as those that make a close bypass are considered. In addition to the parameters common to HURDAT2 (e.g., latitude, longitude, maximum winds, and central pressure), the U.S. hurricane compilation also includes the outer closed isobar, the mean size of the outer closed isobar, and, when available, the radius of maximum wind (RMW). These parameters provide information regarding the size of the hurricanes, which can vary considerably from system to system. For these TCs, winds listed in HURDAT2 at landfall are now consistent with the assigned Saffir-Simpson hurricane scale category, which was not the case in the original HURDAT2 database before the reanalysis efforts. For most U.S. hurricanes of this era, a central pressure observation or quantitatively derived estimate was obtained from original sources, which was then used to determine maximum wind speeds through the application of one of the Brown et al. (2006) pressure-wind relationships. In cases where there was no central pressure value directly available, the estimated winds at landfall were used via the pressure-wind relationship to back out a reasonable central pressure. In either case, the objective was to provide both an estimate of the maximum wind and a central pressure at landfall for all U.S. hurricanes. (Figure S4 in the supplemental material provides the surface wind swath for many of these U.S. landfalling hurricanes.) 


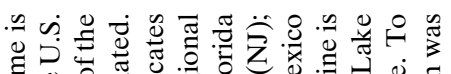
国

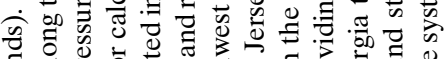

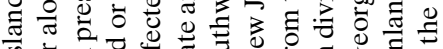
क्ञ

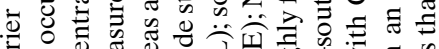

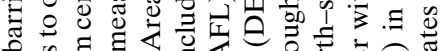

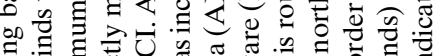

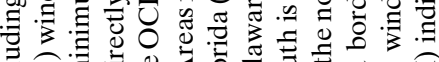

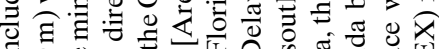

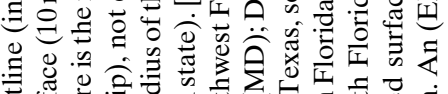

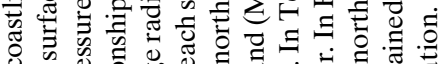
0.

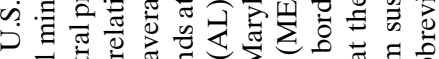

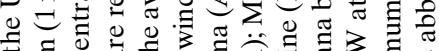

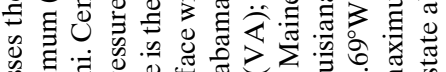

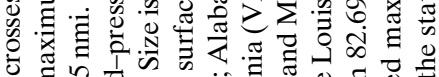

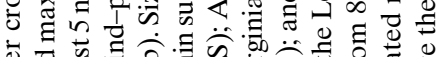

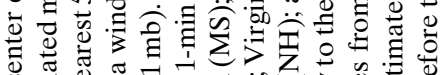
ठ

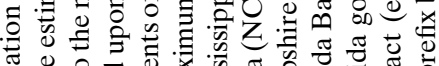

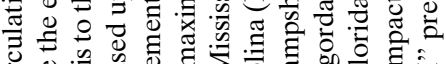

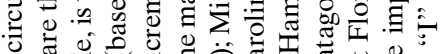

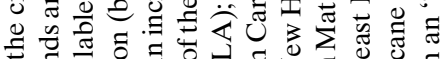

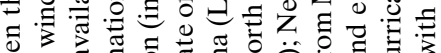

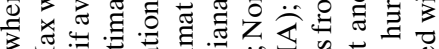

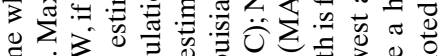

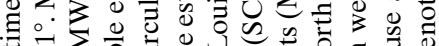

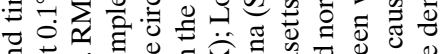

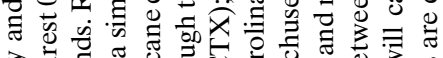

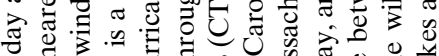

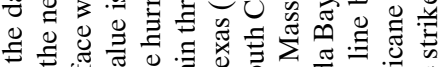

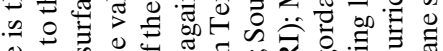

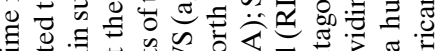

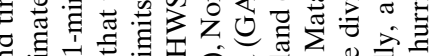

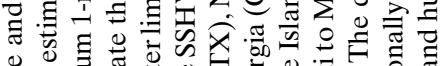

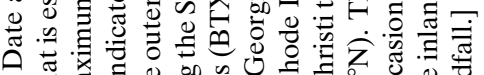

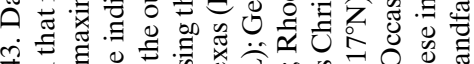

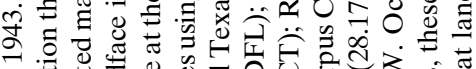

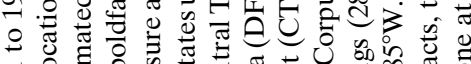

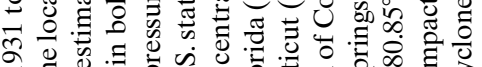

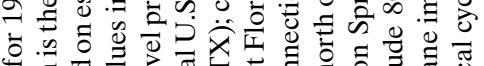

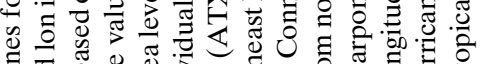

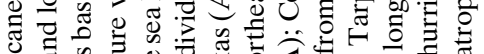

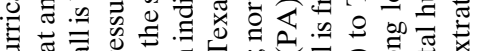

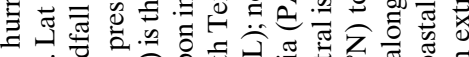

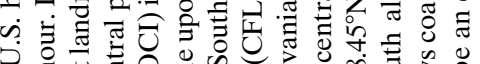
$\supset$ 至 0

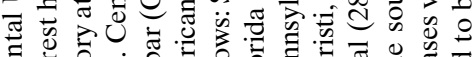

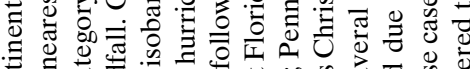

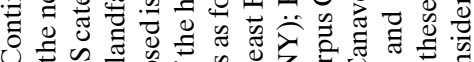

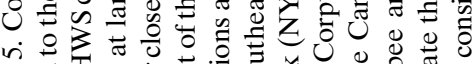

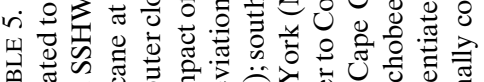

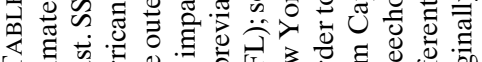

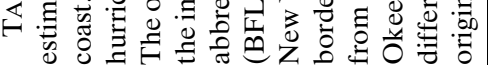

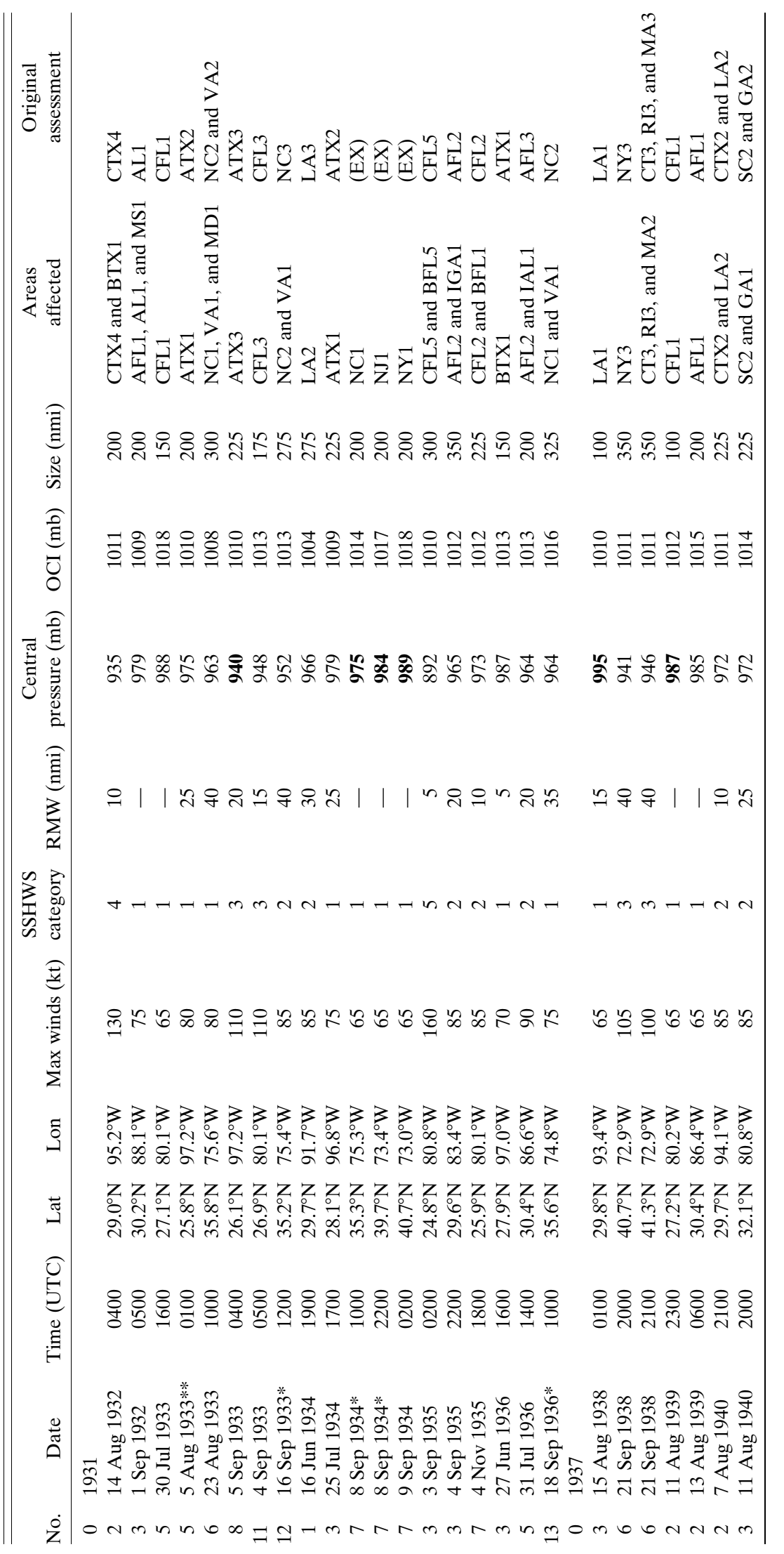




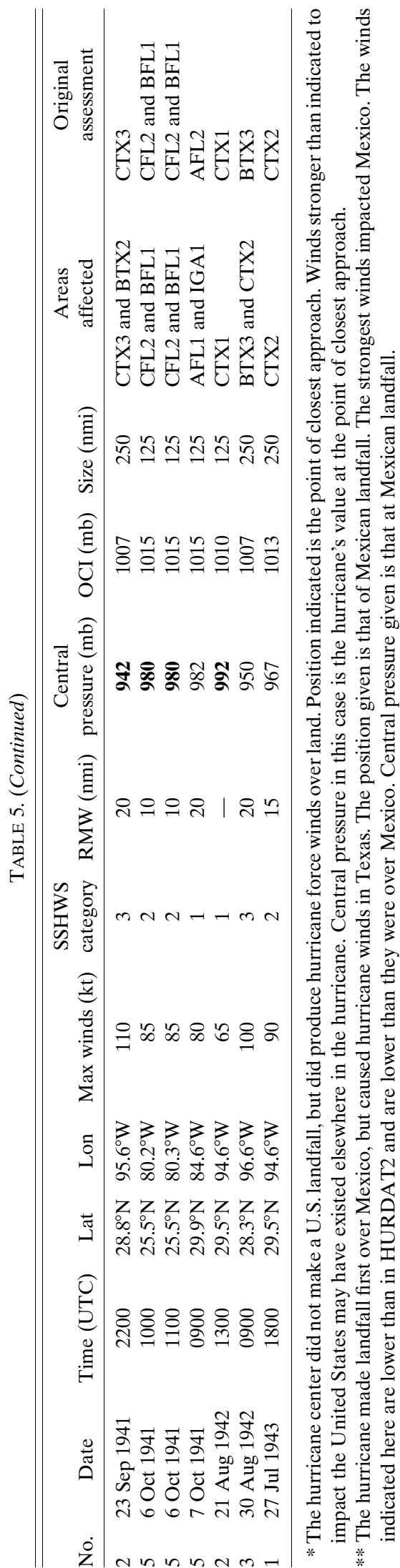

There were 25 U.S. hurricanes (7 major hurricanes) during the 1931-43 period after the reanalysis. No U.S. hurricanes were recorded in either 1931 or 1937 . The total of 25 U.S. hurricanes represents one more hurricane than the original HURDAT2 database contained. Storm 7 in 1934 is now considered as being a hurricane landfall in New York (as well as a hurricane impact both in North Carolina and New Jersey), while previously the system was considered to have transitioned to an extratropical cyclone before landfall. For existing U.S. hurricanes, none were upgraded in category, 17 were unchanged in category, and 7 were downgraded by one category: storm 5 of 1933 from a category 2 in Texas to a category 1; storm 7 of 1933 from a category 2 in North Carolina and Virginia to a category 1 in both states; storm 12 of 1933 from a category 3 in North Carolina to a category 2; storm 1 of 1934 from a category 3 in Louisiana to a category 2; storm 3 of 1934 from a category 2 in Texas to a category 1; storm 5 of 1936 from a category 3 in Florida to a category 2; and storm 13 of 1936 from a category 2 in North Carolina to a category 1 . No original U.S. hurricanes were removed as such from HURDAT2 during the 1931-43 time period. Because of the downgrades listed above for storm 12 of 1933, storm 1 of 1934, and storm 5 of 1936, three major hurricanes were removed from the U.S. hurricane list, while no new major hurricanes impacting the United States were introduced.

Notable hurricanes that affected the continental United States for 1931 through 1943 (Blake et al. 2007) include storm 2 of 1932 (the Freeport Hurricane), in Texas; storm 3 of 1935 (the Labor Day Hurricane), in Florida and Georgia; and storm 5 of 1938 (the Great New England Hurricane), in New York and New England.

The Freeport Hurricane struck the upper coast of Texas on 14 August 1932. The hurricane killed 40 people on impact primarily from storm surge and wind-caused destruction. The cyclone is reanalyzed to have had a rather small inner core with a radius of maximum wind of only $10 \mathrm{nmi}$ and a central pressure of $935 \mathrm{mb}(1 \mathrm{mb}=$ $1 \mathrm{hPa}$ ). This central pressure suggests an intensity of $125 \mathrm{kt}$ from the Brown et al. (2006) north of $25^{\circ} \mathrm{N}$ intensifying cyclone's pressure-wind relationship. ${ }^{3}$

\footnotetext{
${ }^{3}$ As previously discussed in Landsea et al. (2011), it has been considered to use a more realistic pressure-wind relationship such as that provided by Courtney and Knaff (2009). However, this requires a measure of the size of tropical cyclones, such as radius of 34-kt winds, which was only rarely available in this era. Moreover, use of the Courtney-Knaff-Zehr pressure-wind relationship in the 1930s and 1940s would necessitate its inclusion for all tropical cyclones back to the beginning of the database in 1851 to avoid introducing a discontinuity. Such inclusion is left for future researchers to explore.
} 
Intensity at landfall is assessed slightly higher because of the smaller than climatologically expected RMW (Vickery et al. 2000) at $130 \mathrm{kt}$ (category 4 on the SaffirSimpson hurricane wind scale) making it one of seven category 4 hurricanes to strike the Texas coast going back to at least 1880, when reliable records began for the Texas coast. Originally, the cyclone was assessed in HURDAT2 as having $125 \mathrm{kt}$ at the last synoptic time before landfall and being category 4 , so little intensity change was introduced for this U.S. major hurricane.

The most intense hurricane ever known to have struck the United States impacted the Florida Keys on 3 September 1935. The Labor Day Hurricane, so named as it made landfall on Labor Day, is the eighth most deadly storm to impact the continental United States in history. Approximately 400 deaths were reported from an enormous storm surge and extreme wind-caused effects. The lowest sea level pressure ever recorded in the United States-a central pressure of $892 \mathrm{mb}$ - suggests an intensity of $164 \mathrm{kt}$ from the Brown et al. (2006) intensifying subset of cyclones south of $25^{\circ} \mathrm{N}$ pressure-wind relationship and $162 \mathrm{kt}$ from the Brown et al. (2006) intensifying subset of cyclones north of $25^{\circ} \mathrm{N}$ pressure-wind relationship (the hurricane made landfall just south of the $25^{\circ} \mathrm{N}$ latitude). The somewhat compensating effects of a slow $(7 \mathrm{kt})$ translational velocity along with an extremely tiny radius of maximum wind ${ }^{4}(5 \mathrm{nmi})$ led to an analyzed intensity at landfall of $160 \mathrm{kt}$ (category 5). This is the highest intensity for a U.S. landfalling hurricane in HURDAT2, as 1969's Hurricane Camille has been recently reanalyzed (Landsea et al. 2014) to have the second highest landfalling intensity with $150 \mathrm{kt}$. There have been only four category 5 hurricanes to strike the United States since relatively complete records for the entire coast began around 1900: the 1928 San Felipe Hurricane in Puerto Rico, the 1935 Labor Day Hurricane, 1969's Camille, and 1992's Andrew in southeast Florida. The 160-kt landfall intensity for the Labor Day Hurricane represents a 20-kt increase from that originally in HURDAT2, a major change, although the original value also was within the category 5 range. It is of note that public interest

\footnotetext{
${ }^{4}$ It is of note that Ho et al. (1987) reported RMW for U.S. landfalling hurricanes to the nearest $1 \mathrm{nmi}$, which is precision likely beyond what is justifiable. The hurricane database reanalysis project has instead decided to provide such RMW to the nearest $5 \mathrm{nmi}$. For this particular case of the 1935 Labor Day Hurricane, the track was quite well known while moving over the Florida Keys and there existed several eyewitness and barometric readings of the duration of calm conditions and low pressure. These provide credible evidence for an extremely tiny eye and RMW. It is possible that the RMW was as large as $10 \mathrm{nmi}$, but the balance of the data suggested the $5 \mathrm{nmi}$ was a better estimate.
}

continues for this historic hurricane, as two recent nontechnical books have been published about it (Drye 2002; Knowles 2009).

The Great New England Hurricane made landfall in New York and then Connecticut on 21 September 1938. Figure 3 provides the wind swath for this hurricane over New England based on the AEF model. During its landfall, 256 people perished, primarily from the extreme storm surge that accompanied this hurricane. If the same hurricane were to strike that region today, it is estimated that the impact would cause around $\$ 41$ billion in direct damages (Blake et al. 2007). The system had a large (roughly $40 \mathrm{nmi}$ ) radius of maximum wind and central pressure of $941 \mathrm{mb}$ at its first landfall in New York (and about $946 \mathrm{mb}$ at the second landfall in Connecticut), but it had a very fast translational velocity of about $40 \mathrm{kt}$. The 941-mb central pressure suggests an intensity of $103 \mathrm{kt}$ from the Landsea et al. (2004a) north of $35^{\circ} \mathrm{N}$ pressurewind relationship. The highest reliable wind observation recorded on land that was not influenced by terrain effects was a 1-min 95-kt value at Fishers Island, New York. Because of somewhat compensating effects of the storm's rapid speed and large radius of maximum wind, the assessed intensity was $105 \mathrm{kt}$ at the New York landfall and $100 \mathrm{kt}$ at the Connecticut landfall. The hurricane was retained as a category 3 hurricane at its landfall in both New York and New England, although the peak sustained winds at landfall in New York were increased from $85 \mathrm{kt}$ in the original HURDAT2 database to $105 \mathrm{kt}$ in the revision. ${ }^{5}$ The $105-\mathrm{kt}$ landfall intensity makes it the strongest hurricane on record to strike New York and New England dating back to the advent of HURDAT2 in 1851. However, there is evidence (e.g., Boose et al. 2001; Jarvinen 2006) that the 1635 Colonial Hurricane that impacted southeastern New England was as strong as or slightly stronger than the 1938 hurricane at landfall. While New York, Connecticut, and Rhode Island were retained as category 3 impacts from this 1938 hurricane, Massachusetts was downgraded to a category 2 impact in part as a result of the AEF model output. Like the Labor Day Hurricane, the devastating Great New England Hurricane of 1938 continues to generate public interest as

\footnotetext{
${ }^{5}$ The discrepancy between the category 3 original assessment for U.S. landfall of this hurricane with the 85-kt winds existing originally in HURDAT2 is quite a common problem in the existing dataset. Much of the discrepancy is due to reliance primarily upon the central pressure by Hebert and Taylor (1975) to provide the original Saffir-Simpson hurricane wind scale category at landfall in the United States, while the practice today at the National Hurricane Center and within the Hurricane Database Reanalysis Project is to determine the maximum winds at landfall and then let these provide the appropriate category.
} 

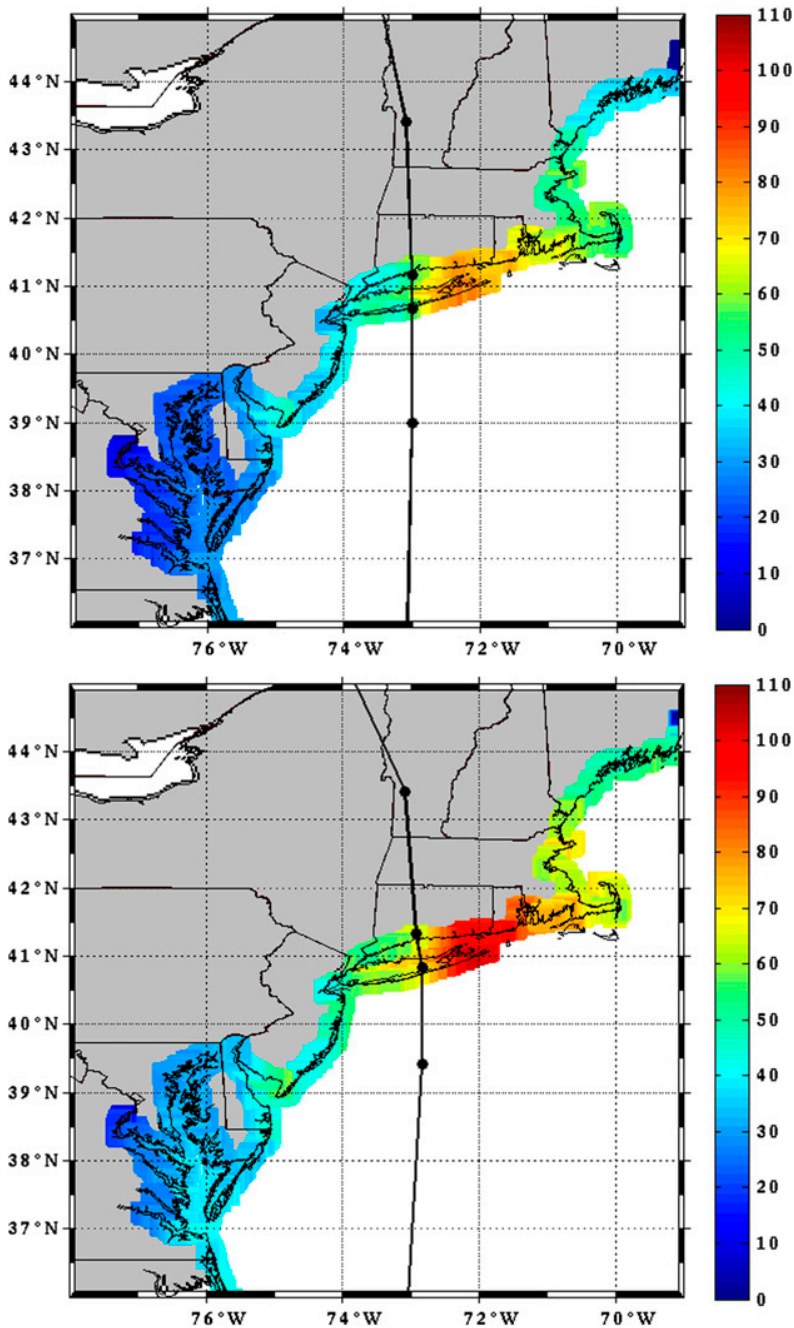

FIG. 3. (top) Original and (bottom) revised track and coastal wind swaths (kt) for the 1938 Great New England Hurricane. The coastal wind swaths were obtained from the AEF wind model.

evidenced by the nontechnical books by Scotti (2003) and Aviles (2013).

\section{c. Major hurricanes outside of the continental United States}

Outside of the continental United States, 12 major hurricanes made landfall either in the Lesser Antilles, Greater Antilles, Central America, or Mexico during 1931-43 (Table 6). This was an exceptionally busy and destructive period with four TCs (two were major landfalling hurricanes) in the top 20 list of all-time most fatalities in the history of the Atlantic basin (Rappaport and FernándezPartagás 1995). Of the 12 storms, 5 were newly designated to be a major hurricane after the reanalysis: storm 9 (San Ciprián) in 1932 that struck Puerto Rico [the winds from which were increased from 95 to $125 \mathrm{kt}$ (category 4) at landfall]; storm 8 in 1933 that struck the Bahamas and Cuba [the winds from which were increased from 70 to $140 \mathrm{kt}$ (category 5) in the Bahamas and 85 to $105 \mathrm{kt}$ (category 3) in Cuba]; storm 14 in 1933 that struck Mexico [the winds from which were increased from 90 to $120 \mathrm{kt}$ (category 4)]; storm 4 in 1938 that struck Mexico [the winds from which were increased from 85 to $105 \mathrm{kt}$ (category 3)]; and storm 5 in 1941 that struck Bahamas [the winds from which were increased from 90 to $105 \mathrm{kt}$ (category 3)].

Belize was impacted by a category 4 hurricane in September 1931, killing about 2500 people, primarily from storm surge (Rappaport and Fernández-Partagás 1995). A peripheral pressure of $952 \mathrm{mb}$ was observed at Belize City, which suggested an intensity of at least $109 \mathrm{kt}$ from the Brown et al. (2006) south of $25^{\circ} \mathrm{N}$ pressure-wind relationship. A $115-\mathrm{kt}$ intensity at landfall was analyzed, although this is conservative if the actual central pressure was substantially deeper than about $945-950 \mathrm{mb}$.

The Bahamas was impacted by two category 5 hurricanes during this period-storm 4 in September 1932 and storm 8 in August 1933. A peripheral pressure of $931 \mathrm{mb}$ measured at Great Abaco in the former storm suggests maximum winds of at least $128 \mathrm{kt}$ from the subset of intensifying hurricanes from the Brown et al. (2006) north of $25^{\circ} \mathrm{N}$ pressure-wind relationship. An intensity of $140 \mathrm{kt}$ is analyzed at landfall for storm 4 of 1932 in the Bahamas. A peripheral ship observation in the latter storm simultaneously measured a $930-\mathrm{mb}$ pressure and hurricane force winds, suggesting maximum winds of at least $130 \mathrm{kt}$ from the Brown et al. (2006) south of $25^{\circ} \mathrm{N}$ pressure-wind relationship. An intensity of $140 \mathrm{kt}$ is analyzed at landfall for storm 8 of 1933 in the Bahamas. Both extreme hurricanes were limited in their destruction as the core of the cyclones avoided most towns and cities in the Bahamas.

Another major hurricane in 1932 (storm 9, also known as San Ciprián) struck Puerto Rico in September 1932. This cyclone killed 257 people primarily from windcaused destruction. A central pressure of $943 \mathrm{mb}$ was obtained by averaging two ship measurements taken from within the eye near Ensenada Honda. This suggests maximum winds of $118 \mathrm{kt}$ from the Brown et al. (2006) south of $25^{\circ} \mathrm{N}$ pressure-wind relationship. Because of a rather small radius of maximum wind, 5$10 \mathrm{nmi}$ based upon eyewitness accounts of the duration of calm in the eye, the intensity at landfall is assessed slightly higher at $125 \mathrm{kt}$.

The largest impact of any major hurricane from 1931 to 1943 was the devastating category 4 hurricane that struck the Cayman Islands and Cuba in November 1932 (storm 14 of 1932) and killed over 3100 people (Rappaport and Fernández-Partagás 1995) primarily from a storm surge that reached at least $6.8 \mathrm{~m}$. While this system had extremely 


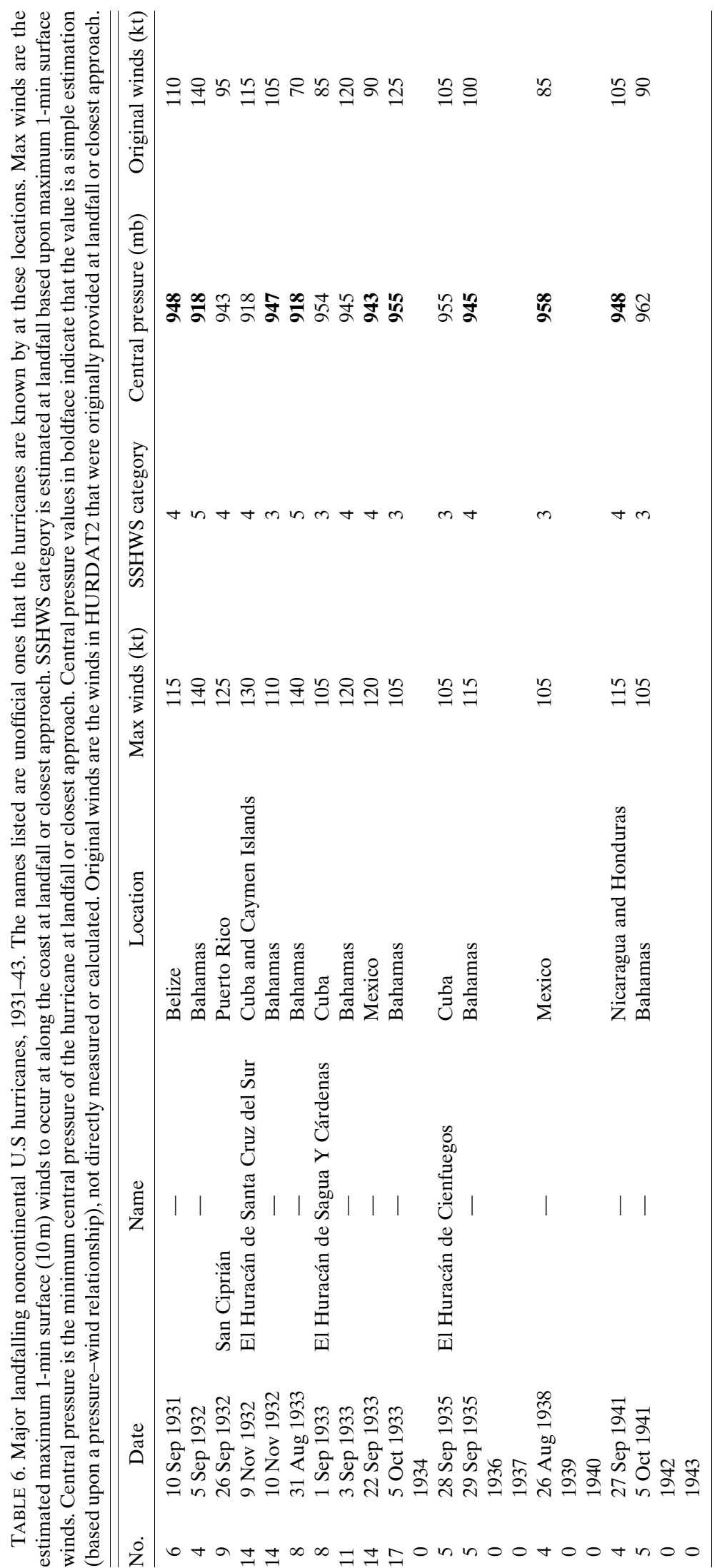


low 918-mb central pressure at landfall in Cuba (Perez et al. 2000), a 30-35-nmi radius of maximum wind and a low environmental pressure indicate an intensity (130 kt) that is substantially lower than the Brown et al. (2006) south of $25^{\circ} \mathrm{N}$ pressure-wind relationship for that central pressure $(140 \mathrm{kt})$.

Two other cyclones caused enormous destruction and fatalities resulting from rain-caused flash floods and mudslides (Rappaport and Fernández-Partagás 1995): storm 1 of 1934 in El Salvador and Honduras and storm 6 of 1935 in Haiti, Jamaica, and Honduras. The former cyclone spent several days looping over Central America as a tropical storm and caused torrential rains that lead to the death of at least 3000 people. The latter system reached hurricane intensity over the Caribbean Sea and meandering for several days, leading to devastating rainfall impacts and over 2150 fatalities in Haiti, Honduras, and Jamaica. Neither cyclone reached major hurricane status, but both were in the top 20 largest loss of life systems in the history of the Atlantic basin (Rappaport and Fernández-Partagás 1995).

To summarize the significant changes to the landfall intensity of these 12 major landfalling (noncontinental United States) hurricanes (Table 6), 4 had large increases in landfall intensity [storm 9 of 1932 (San Ciprián) from 95 to $125 \mathrm{kt}$ in Puerto Rico; storm 8 of 1932 in the Bahamas from 70 to $140 \mathrm{kt}$ and in Cuba (El Huracán de Sagua y Cárdenas) from 85 to $105 \mathrm{kt}$; storm 14 of 1933 from 90 to $120 \mathrm{kt}$ in Mexico; and storm 4 of 1938 from 85 to $105 \mathrm{kt}$ in Mexico], one had a large decrease in landfall intensity (storm 17 of 1933 from 125 to $105 \mathrm{kt}$ in the Bahamas), and the remainder had small or no alterations in landfall intensity. None of these major landfalling hurricanes had major changes to their track around the time of their landfall.

\section{Summary}

The hurricane reanalysis has been completed now through the early 1940s, up to the advent of aircraft reconnaissance. While the results provided here are just brief highlights and summaries of the thousands of changes introduced into the Atlantic hurricane database, detailed information on all raw observations, the original and revised HURDAT2, annual track maps, metadata regarding changes for individual TCs, and comments from/replies to the National Hurricane Center's Best Track Change Committee can be found online (at http://www.aoml.noaa.gov/hrd/data_sub/ re_anal.html).

Highlights of accomplishments attained for this stage of the Atlantic Hurricane Database Reanalysis Project for 1931-43 include the following:
1) Track alterations were implemented for nearly all TCs in the existing HURDAT2, although the majority were for minor changes.

2) Intensity changes were made to nearly all TCs with a proportionally large number of major alterations made to intensity (both stronger and weaker) compared with the track.

3) There were 23 new TCs discovered and added into HURDAT2, while five systems were removed from the database: one was the continuation of an earlier TC, two were only of tropical depression intensity at their peak, and two were extratropical cyclones.

4) While the overall annual frequency of TCs that occurred during the era increased from 10.0 to $11.4 \mathrm{yr}^{-1}$, smaller increases were noted in the number of hurricanes and major hurricanes. The overall activity—as denoted by accumulated cyclone energy_increased by about $9 \%$.

5) There were 25 continental U.S. hurricanes examined, one of which was newly analyzed to be a hurricane (rather than an extratropical storm) at landfall. Of the 24 U.S. hurricanes in the original database, 17 had no changes introduced for the peak category and 7 were downgraded a category. Seven major continental U.S. hurricanes were analyzed for 1931-43, which is three less than originally indicated in HURDAT2 due to adjusting the SSHWS category downward from 3 to 2 at landfall.

6) There were 12 major hurricanes that struck other regions in the Atlantic basin, 5 of which were newly classified as major hurricanes. The reanalysis resulted in large (at least $20 \mathrm{kt}$ ) landfall intensity increases for four of these storms and a large intensity reduction for one storm.

7) Despite the reanalysis changes, significant uncertainty exists in TC tracks, significant undercounts in TC frequency, and significant underestimation of TC intensity and duration, especially for those systems over the open ocean.

Acknowledgments. This work has been sponsored by a grant from the NOAA Climate Program Office on "Atlantic basin tropical cyclone database reanalysis and impact of incomplete sampling." The component that included the AEF wind model work was supported by a grant from the Risk Prediction Initiative on "A reanalysis of ten U.S. landfalling hurricanes." The authors wish to thank the current NHC Best Track Change Committee (Chairman Jack Beven, Eric Blake, Todd Kimberlain, Richard Pasch, Gladys Rubio, and Eric Uhlhorn) and past members (Lixion Avila, Hugh Cobb, Jim Gross, Brian Jarvinen, Colin McAdie, and Ed Rappaport) for their encouragement and detailed suggestions that 
have helped to quality control the thousands of alterations and additions to HURDAT2. Special thanks for their individual contributions toward this project for this era are also given to Gloria Aversano and the NHC regional library, James Belanger, Auguste Boissonnade and Risk Management Solutions, Mike Chenoweth, Gil Clark, Sandy Delgado, Daniel Gladstein, Mark Jelinek, Cary Mock, Charlie Neumann, Astryd Rodriguez, David Roth, and Mark Zimmer. Joan David kindly prepared the track map figures utilized in this paper.

\section{REFERENCES}

Aviles, L. B., 2013: Taken by Storm 1938: A Social and Meteorological History of the Great New England Hurricane. Amer. Meteor. Soc., 265 pp.

Bell, G. D., and Coauthors, 2000: Climate assessment for 1999. Bull. Amer. Meteor. Soc., 81, S1-S50, doi:10.1175/ 1520-0477(2000)81[s1:CAF]2.0.CO;2.

Blake, E. S., E. N. Rappaport, and C. W. Landsea, 2007: The deadliest, costliest, and most intense United States tropical cyclones from 1851 to 2006 (and other frequently requested hurricane facts). NOAA Tech. Memo. NWS-TPC-5, 43 pp. [Available online at http://www.nhc.noaa.gov/pdf/NWS-TPC-5.pdf.]

Boose, E. R., K. E. Chamberlin, and D. R. Foster, 2001: Landscape and regional impacts of hurricanes in New England. Ecol. Monogr., 71, 27-48.

Brown, D. P., J. L. Franklin, and C. W. Landsea, 2006: A fresh look at tropical cyclone pressure-wind relationships using recent reconnaissance-based "best track" data (1998-2005). 27th Conf. on Hurricanes and Tropical Meteorology, Monterey, CA, Amer. Meteor. Soc., 3B.5. [Available online at http://ams.confex.com/ ams/pdfpapers/107190.pdf.]

Courtney, J., and J. A. Knaff, 2009: Adapting the Knaff and Zehr wind-pressure relationship for operational use in tropical cyclone warning centres. Aust. Meteor. Oceanogr. J., 58, 167-179.

Dickinson, M., G. D. Rowe, R. Richardson, I. Ginis, and L. Rothstein, 2004: Use of numerical weather prediction technology for simulations of historic tropical cyclones. 26th Conf. on Hurricanes and Tropical Meteorology, Miami, FL, Amer. Meteor. Soc., 16C.4. [Available online at https://ams.confex.com/ams/ 26HURR/techprogram/paper_75936.htm.]

Drye, W., 2002: Storm of the Century: The Labor Day Hurricane of 1935. National Geographic Society, 326 pp.

Hagen, A. B., and C. W. Landsea, 2012: On the classification of extreme Atlantic hurricanes utilizing mid-twentieth-century monitoring capabilities. J. Climate, 25, 4461-4475, doi:10.1175/ JCLI-D-11-00420.1.

- D. Dtrahan-Sakoskie, and C. Luckett, 2012: A reanalysis of the 1944-53 Atlantic hurricane seasons-The first decade of aircraft reconnaissance. J. Climate, 25, 4441-4460, doi:10.1175/ JCLI-D-11-00419.1.

Hebert, P. J., and G. Taylor, 1975: Hurricane experience levels of coastal county populations from Texas to Maine. National Weather Service Community Preparedness Staff and Southern Region Special Rep., 153 pp.

Ho, F. P., J. C. Su, K. L. Hanevich, R. J. Smith, and F. P. Richards, 1987: Hurricane climatology for the Atlantic and Gulf coasts of the United States. NOAA Tech. Rep. NWS 38, 193 pp.

Jarvinen, B. R., 2006: Storm tides in twelve tropical cyclones (including four intense New England hurricanes). Rep. for
FEMA/National Hurricane Center, 99 pp. [Available online at http://www.aoml.noaa.gov/hrd/Landsea/12Tides.pdf.]

Jelesnianski, C. P., J. Chen, and W. A. Shaffer, 1992: SLOSH: Sea, Lake, and Overland Surges from Hurricanes. NOAA Tech. Rep. NWS48, 71 pp.

Knowles, T. N., 2009: Category 5: The 1935 Labor Day Hurricane. University Press of Florida, $350 \mathrm{pp}$.

Kurihara, Y., R. E. Tuleya, and M. A. Bender, 1998: The GFDL hurricane prediction system and its performance in the 1995 hurricane season. Mon. Wea. Rev., 126,1306-1322, doi:10.1175/ 1520-0493(1998)126<1306:TGHPSA > 2.0.CO;2.

Landsea, C. W., and J. L. Franklin, 2013: Atlantic hurricane database uncertainty and presentation of a new database format. Mon Wea. Rev., 141, 3576-3592, doi:10.1175/MWR-D-12-00254.1.

_ , and Coauthors, 2004a: The Atlantic hurricane database reanalysis project: Documentation for the 1851-1910 alterations and additions to the HURDAT database. Hurricanes and Typhoons: Past, Present and Future, R. J. Murnane and K.-B. Liu, Eds., Columbia University Press, 177-221.

_ and Coauthors, 2004b: A reanalysis of Hurricane Andrew's intensity. Bull. Amer. Meteor. Soc., 85, 1699-1712, doi:10.1175/ BAMS-85-11-1699.

_ and Coauthors, 2008: A reanalysis of the 1911-20 Atlantic hurricane database. J. Climate, 21, 2138-2168, doi:10.1175/ 2007JCLI1119.1.

— G. A. Vecchi, L. Bengtsson, and T. R. Knutson, 2010: Impact of duration thresholds on Atlantic tropical cyclone counts. J. Climate, 23, 2508-2519, doi:10.1175/2009JCLI3034.1.

—, S. Feuer, A. Hagen, D. A. Glenn, J. Sims, R. Perez, M. Chenoweth, and N. Anderson, 2012: A reanalysis of the 1921-1930 Atlantic hurricane database. J. Climate, 25, 865885, doi:10.1175/JCLI-D-11-00026.1.

_ Hurricane Camille. Recorded Presentation, 31st Conf. on Hurricanes and Tropical Meteorology, San Diego, Amer. Meteor. Soc., 5C.8. [Available online at https://ams.confex.com/ams/ 31Hurr/webprogram/Paper244128.html.]

Perez Suarez, R., R. Vega, and M. Limia, 2000: Cronología de los Ciclones Tropicales de Cuba. Instituto de Meteorología, 100 pp.

Rappaport, E. N., and J. Fernández-Partagás, 1995: The deadliest Atlantic tropical cyclones, 1492-1994. NOAA Tech. Memo. NWS NHC-47, 41 pp. [Available online at http://www.nhc.noaa.gov/ pdf/NWS-NHC-1995-47.pdf.]

Scotti, R. A., 2003: Sudden Sea: The Great Hurricane of 1938. Little, Brown and Company, 279 pp.

Sumner, H. C., 1943: North Atlantic hurricanes and tropical disturbances of 1943. Mon. Wea. Rev., 71, 179-183, doi:10.1175/ 1520-0493(1943)71<179:NAHATD $>2.0 . C O ; 2$.

Vecchi, G. A., and T. R. Knutson, 2008: On estimates of historical North Atlantic tropical cyclone activity. J. Climate, 21, 35803600, doi:10.1175/2008JCLI2178.1.

- , and - 2011: Estimating annual numbers of Atlantic hurricanes missing from the HURDAT database (1878-1965) using ship track density. J. Climate, 24, 1736-1746, doi:10.1175/ 2010JCLI3810.1.

Vickery, P. J., P. F. Skerlj, and L. A. Twisdale, 2000: Simulation of hurricane risk in the U.S. using empirical track model. J. Struct. Eng., 126, 1222-1237, doi:10.1061/(ASCE)0733-9445(2000)126: 10(1222).

Villarini, G., G. A. Vecchi, T. R. Knutson, and J. A. Smith, 2011: Is the recorded increase in short duration North Atlantic tropical storms spurious? J. Geophys. Res., 116, D10114, doi:10.1029/ 2010JD015493. 